\title{
14. OLIGOCENE TO RECENT CALCAREOUS NANNOPLANKTON FROM THE PHILIPPINE SEA, DEEP SEA DRILLING PROJECT LEG 59
}

\author{
Erlend Martini, Geologisch-Paläontologisches Institut der Universität, Frankfurt am Main, Germany
}

\section{INTRODUCTION}

During Leg 59 of the Deep Sea Drilling Project, five sites (447 to 451) were occupied and seven holes drilled between Okinawa and Guam in the Philippine Sea (Fig. 1). All holes except Hole 447 yielded common calcareous nannoplankton at certain intervals cored. Nannoplankton assemblages and their age assignments will be discussed for each site, and fossil lists for selected samples from Holes 447A, 448, 450, and 451 are presented in Tables 1 to 4 , covering the middle Oligocene to the Quaternary.

\section{CALCAREOUS NANNOPLANKTON ZONATION}

For the Tertiary and Quaternary, I have used the standard calcareous nannonplankton zonation (Martini, 1971) (Fig. 2). Because of the tropical position of the sites occupied, however, the following deviations are necessary.

\section{NN 13/14 (Combined Ceratolithus rugosus/Discoaster asymmetricus Zone)}

Definition: Interval from the first occurrence of Ceratolithus rugosus Bukry and Bramlette to the last occurrence of $C$. tricorniculatus Gartner.

Remarks: Because Discoaster asymmetricus Gartner was not found in the sampled material of Hole 451, and there is otherwise no reason for the presence of a hiatus within Cores 4 and 5 of Hole 451, a combined NN 13/14 Zone seems more realistic.

\section{NN 4 (Helicosphaera ampliaperta Zone)}

Substitute definition: Interval from the last occurrence of Sphenolithus belemnos Bramlette and Wilcoxon to the first occurrence of $D$. exilis Martini and Bramlette.

Remarks: As the guide fossil $H$. ampliaperta (Bramlette and Wilcoxon) seems to be absent in the tropical Pacific, D. exilis Martini and Bramlette is taken to define the top of Zone NN 4 (Martini and Worsley, 1971).

\section{NP 25 (Sphenolithus ciperoensis Zone)}

Substitute definition: Interval from the last occurrence of $S$. distentus (Martini) to the last occurrence of $S$. ciperoensis Bramlette and Wilcoxon.

Remarks: The guide fossil $H$. recta $(\mathrm{Haq})(=H$. truncata Bramlette and Wilcoxon) is not present or is too rare in the tropical Pacific, as already noted by Martini and Worsley (1971); thus $S$. ciperoensis is used as a substitute species. Its last occurrence marks the top of Zone NP 25 in Leg 59.

A different zonation, mainly based on Bukry (1971a, 1973), was used during Leg 31 in the Western Philippine Sea and during Leg 60 at the eastern transect of the Philippine Sea. For better comparison of results both zonations and their correlation are shown in Figure 2. The zonations differ in some parts of the tabulated time interval but are otherwise very similar because 20 boundaries are identical in both zonations. There is also general agreement on the age of some major boundaries, indicated by an asterisk in Figure 2. A few remarks, however, seem necessary to avoid misinterpretation, especially in the Oligocene, where some confusion may arise because the same zonal names are used for different time intervals. The base of the $S$. predistentus Zone in both zonations is taken at the last occurrence of Reticulofenestra umbilica. In the standard zonation, however, the top of the $S$. predistentus Zone (NP 23) is marked by the first occurrence of S. ciperoensis, whereas in Bukry's zonation the top is indicated by the first appearance of $S$. distentus. In the standard zonation, the top of the following zone (S. distentus Zone) is marked by the first occurrence of $S$. ciperoensis. That means that the $S$. predistentus Zone and the $S$. distentus Zone of Bukry are equivalent to Zone NP 23 (S. predistentus Zone) of the standard zonation. The $S$. ciperoensis Zone of Bukry, on the other hand, is equivalent to Zones NP 24 (S. distentus Zone) and NP 25 ( $S$. ciperoensis Zone), because the base is indicated by the first occurrence of $S$. ciperoensis and the top is taken at the last occurrence of the same species in this area, although the top of Zone NP 25 was originally defined by the last occurrence of $H$. recta (see also Martini, 1976). In Figure 2, correlations between both zonations are based on index species. Indication of estimated time relations are taken from Martini (1976) for the standard calcareous nannoplankton zonation. Figure 3 shows a summary of the calcareous nannoplankton stratigraphy of holes drilled during Leg 59.

\section{SITE SUMMARIES}

\section{Site 447}

$$
\left(1^{\circ} 00.88^{\prime} \mathrm{N}, 133^{\circ} 17.37^{\prime} \mathrm{E} \text {, depth } 6022 \mathrm{~m}\right)
$$

At Hole 447, on the eastern side of the West Philippine Basin, only manganese nodules and unfossiliferous brown clay were recovered in the core catcher of Core 1. Recovery in Hole 447A was more successful: although Cores 1 to $4(0-37.5 \mathrm{~m})$ are barren of calcareous nan- 


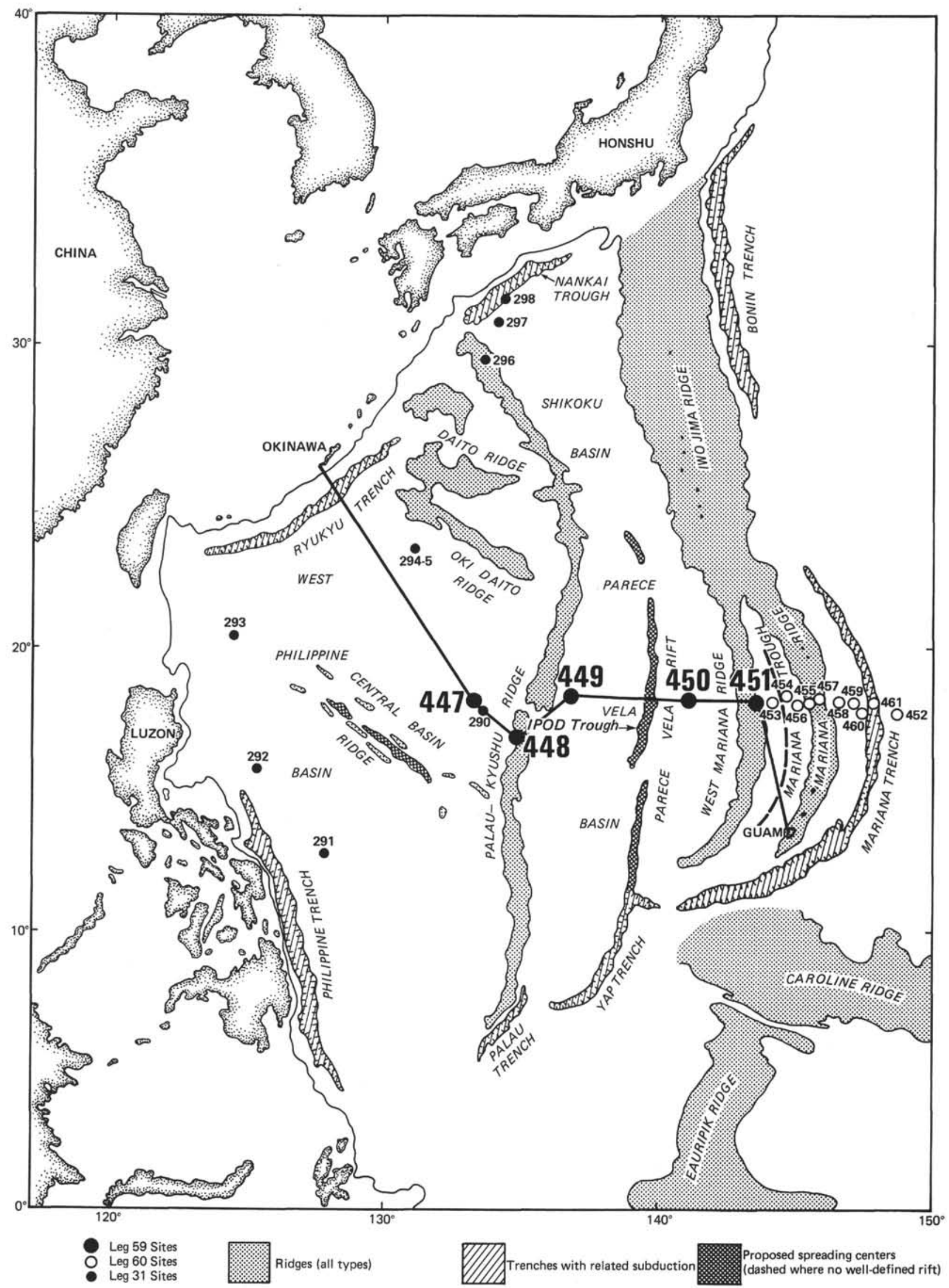

Figure 1. Location of sites drilled during Legs 59, 60, and 31. 


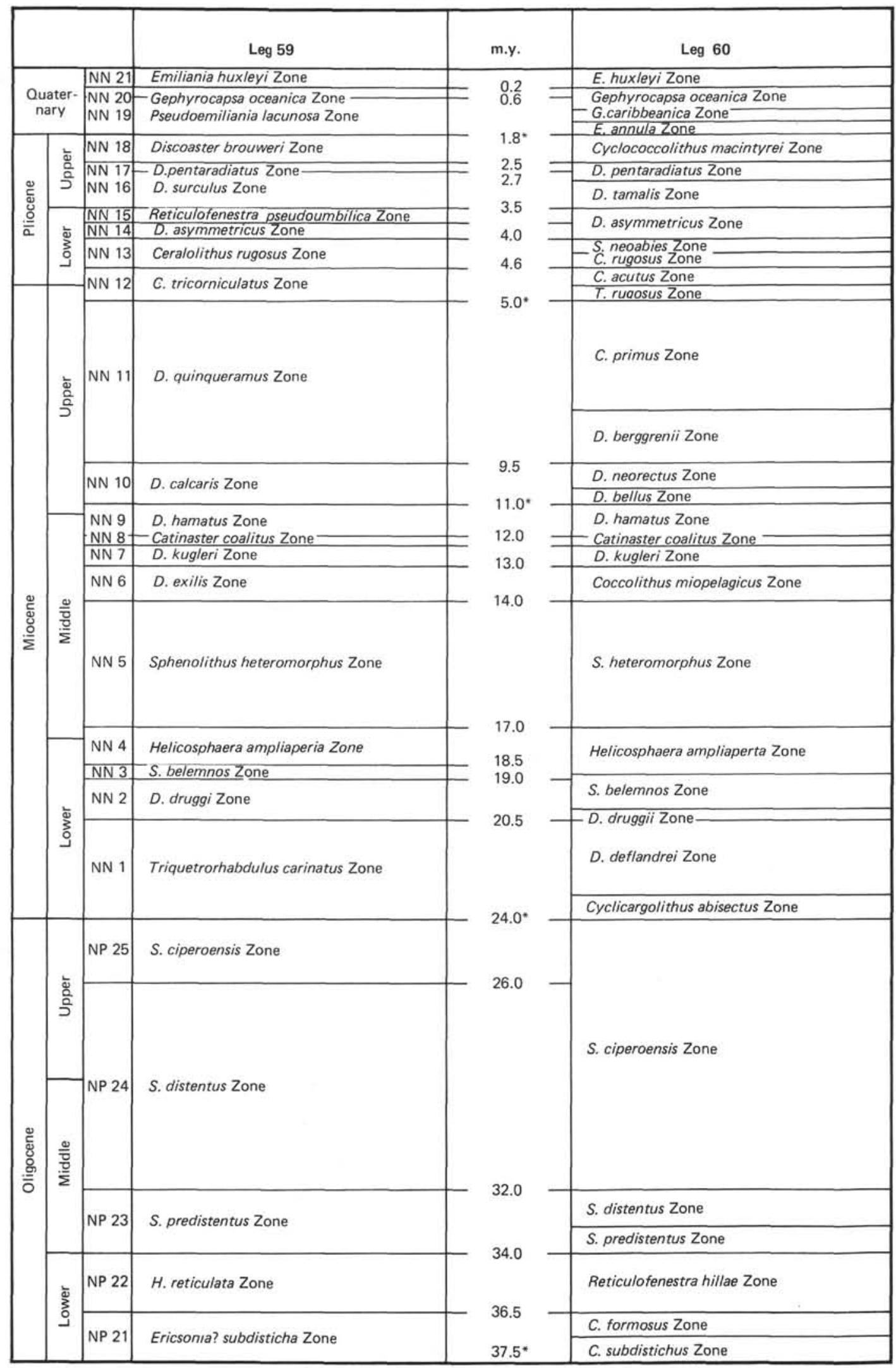

Figure 2. Oligocene to Quaternary standard nannoplankton zonation used during Leg 59, correlation to nannoplankton zonation used during Leg 60, and indication of the estimated time relations (in m.y.) for the standard zonation. (Asterisks indicate generally agreed-upon ages of major boundaries.) 


\begin{tabular}{|c|c|c|c|c|c|c|c|}
\hline & Zones & $447 \mathrm{~A}$ & 448 & $448 \mathrm{~A}$ & 449 & 450 & 451 \\
\hline \multirow{3}{*}{ Quaternary } & NN 21 & & & & & & 1 \\
\hline & NN 20 & & & & & & 2 \\
\hline & NN 19 & & & & & & $1-2$ \\
\hline \multirow{3}{*}{$\begin{array}{l}\text { Upper Pliocene } \\
\text { (Piacenzian) }\end{array}$} & NN 18 & & & & & & 2 \\
\hline & NN 17 & & & & & & $2-3$ \\
\hline & NN 16 & & & & & & 3 \\
\hline \multirow{3}{*}{$\begin{array}{l}\text { Lower Pliocene } \\
\text { (Zanclian) }\end{array}$} & NN 15 & & & & & & 4 \\
\hline & NN 14 & & & & & & \multirow{2}{*}{$4-5$} \\
\hline & NN 13 & & & & & & \\
\hline \multirow{3}{*}{$\begin{array}{c}\text { Upper Miocene } \\
\text { (Tortonian-Messinian) }\end{array}$} & NN 12 & & & & & & 5 \\
\hline & NN 11 & & & & & & $5-20^{\circ}$ \\
\hline & NN 10 & & & & & & $22-85^{\circ}$ \\
\hline \multirow{5}{*}{$\begin{array}{c}\text { Middle Miocene } \\
\text { (Langhian-Serravallian) }\end{array}$} & NN 9 & & 1 & & & $4-6$ & \\
\hline & NN 8 & & 1 & 1 & & $7-8$ & \\
\hline & NN 7 & & 1 & 1 & & $8-12$ & \\
\hline & NN 6 & & 1 & 1 & 6 & $13-18$ & \\
\hline & NN 5 & & $2-4$ & 1 & 7 & $18-35$ & \\
\hline \multirow{4}{*}{$\begin{array}{l}\text { Lower Miocene } \\
\text { (Aquitanian-Burdigalian) }\end{array}$} & NN 4 & & 4 & & & $?$ & \\
\hline & NN 3 & & 4 & & $10-11$ & & \\
\hline & NN 2 & & 5 & 2 & $11-12$ & & \\
\hline & NN 1 & & $6-8$ & $2-3$ & $12-13$ & & \\
\hline $\begin{array}{l}\text { Upper Oligocene } \\
\text { (Chattian) }\end{array}$ & NP 25 & & $10-12$ & 4 & 13 & & \\
\hline \multirow{2}{*}{$\begin{array}{l}\text { Middle Oligocene } \\
\text { (Rupelian) }\end{array}$} & NP 24 & $5-6$ & $13-32^{*}$ & $5-6$ & & & \\
\hline & NP 23 & $\begin{array}{c}7-9 \\
11-12\end{array}$ & $33-51^{\circ}$ & $7-51^{*}$ & & & \\
\hline \multirow{2}{*}{$\begin{array}{l}\text { Lower Oligocene } \\
\text { (Latdorfian) }\end{array}$} & NP 22 & & & & & & \\
\hline & NP 21 & & & & & & \\
\hline
\end{tabular}

* $=$ Calcareous nannoplankton not found in all cores of the listed interval.

गागागा = Contact with basement.

Figure 3. Calcareous nannoplankton stratigraphy of holes drilled during Leg 59. (Numbers refer to cores. * = calcareous nannoplankton not found in all cores of the listed interval. TाIाI = contact with basement.)

noplankton, below a lithologic change between Cores 4 and 5 , calcareous nannofossils are present from the top of Core 5 down to Core $12(37.5-104.0 \mathrm{~m})$, with the exception of Core $10(85.0-94.5 \mathrm{~m})$. The assemblages in most cases are poorly preserved and the specimens heavily etched. In Cores 5 and 6 Sphenolithus ciperoensis is present together with $S$. distentus, $S$. predistentus, Coccolithus abisectus, and Dictyococcites dictyodus, indicating the Oligocene calcareous nannoplankton Zone NP 24 (S. distentus Zone). The same assemblage is present in Cores 7 to 12 , with the exception of $S$. ciperoensis; consequently these samples are placed in calcareous nannoplankton Zone NP 23 (S. predistentus Zone). $C$. abisectus, first occurring at about the same level as $S$. ciperoensis elsewhere and taken as a substitute species for defining the base of Zone NP 24 in high-latitude areas (Müller, 1976), is found in all samples down to Core 12, CC. A similar occurrence of these two species was noted by Ellis (1975) at the nearby Site 290 as well as at Site 296 and may be caused by the high accumulation rate in the area during that particular time interval. Table 1 presents the distribution of calcareous nannoplankton species in selected samples of Hole 447A.
In several samples older species, probably displaced from lower Oligocene deposits, such as Reticulofenestra umbilica, Cyclococcolithus formosus, and Braarudosphaera bigelowi, are found. This indicates continuous erosion in an adjacent area during this time. In Core 13, at a depth of 113.0 meters, we found basalt below middle Oligocene sediments; volcanogenic rocks were recovered in the remaining cores down to the terminal depth of 296.5 meters.

For the uppermost part of the sedimentary column, a Lamont piston core taken very close to Site 447 was available for inspection. Section 1 of Core V34-10 $\left(18^{\circ} 18^{\prime} \mathrm{N}, 133^{\circ} 12^{\prime} \mathrm{E}\right.$, water depth $\left.5899 \mathrm{~m}\right)$ contains brown clay, and samples taken at $13 \mathrm{~cm}, 50 \mathrm{~cm}$, and 140 $\mathrm{cm}$ are barren of calcareous nannoplankton. In a sample from $98 \mathrm{~cm}$, rare displaced Oligocene nannofossils are present.

The upper part of the sedimentary column in Hole $447 \mathrm{~A}$ is closely similar to that at Hole 290 , cored during DSDP Leg 31. At both sites unfossiliferous brown zeolitic clays, which are twice as thick at Hole 290 as in Hole $447 \mathrm{~A}$, are underlain by calcareous sediments with the calcareous nannoplankton Zone NP 24 (S. distentus 
Table 1. Distribution of calcareous nannoplankton in selected samples from Hole 447A and indication of standard nannoplankton zones.

\begin{tabular}{|c|c|c|c|c|c|c|c|c|c|c|c|c|c|c|c|c|c|c|c|}
\hline $\begin{array}{l}\text { Samples } \\
\text { (intervals in } \mathrm{cm} \text { ) }\end{array}$ & 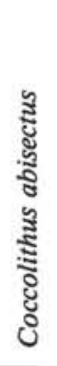 & 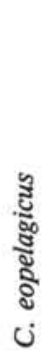 & 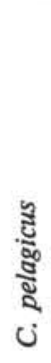 & 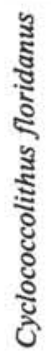 & 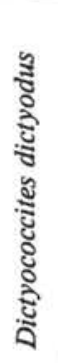 & 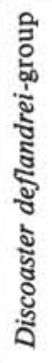 & $\begin{array}{l}\tilde{\Xi} \\
\text { ¿ }\end{array}$ & 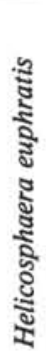 & 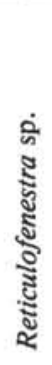 & 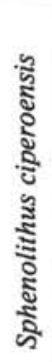 & 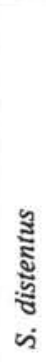 & ڤ & 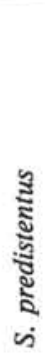 & 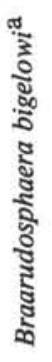 & 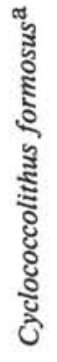 & 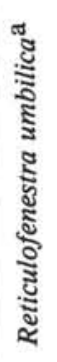 & 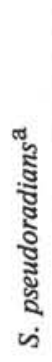 & 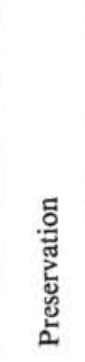 & 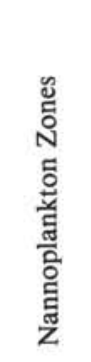 \\
\hline $\begin{array}{l}5-1,35-36 \\
5, C C \\
6-1,20-21 \\
6, C C \\
7-1,5-6\end{array}$ & $\begin{array}{l}\times \\
\times \\
\times \\
\bullet \\
0\end{array}$ & $\begin{array}{l}\times \\
\times \\
\times \\
0 \\
0\end{array}$ & $\begin{array}{l}0 \\
0 \\
\times \\
\times \\
x\end{array}$ & $\begin{array}{l}\bullet \\
\bullet \\
\bullet\end{array}$ & $\begin{array}{l}\times \\
\times \\
\times \\
0 \\
0\end{array}$ & $\begin{array}{l}0 \\
0 \\
x \\
0 \\
0\end{array}$ & $\begin{array}{l}x \\
\times \\
\times \\
0 \\
x\end{array}$ & & & $\times$ & $\begin{array}{l}x \\
x \\
\bullet \\
x\end{array}$ & $\begin{array}{l}x \\
0 \\
x \\
0 \\
x\end{array}$ & $\begin{array}{l}x \\
\times \\
\times \\
0\end{array}$ & & $x$ & $\begin{array}{l}\times \\
0 \\
\times \\
\times \\
\times\end{array}$ & $\begin{array}{l}\times \\
\times\end{array}$ & $\begin{array}{c}\mathrm{P}, \mathrm{M} \\
\mathrm{P} \\
\mathrm{P} \\
\mathrm{P}, \mathrm{M} \\
\mathrm{P}\end{array}$ & NP 24 \\
\hline $\begin{array}{l}7, \mathrm{CC} \\
8, \mathrm{CC} \\
9-2,0-2 \\
9, \mathrm{CC}\end{array}$ & $\begin{array}{l}\times \\
\times \\
0 \\
\times\end{array}$ & $\begin{array}{l}\times \\
\times \\
\times\end{array}$ & $\begin{array}{l}\times \\
\times \\
\times \\
\times\end{array}$ & $\begin{array}{l}0 \\
\bullet \\
0 \\
0\end{array}$ & $\begin{array}{l}0 \\
0 \\
0 \\
0\end{array}$ & $\begin{array}{l}x \\
0 \\
x \\
x\end{array}$ & $\begin{array}{l}x \\
x \\
x \\
x\end{array}$ & $x$ & 0 & & $x$ & $\begin{array}{l}x \\
x \\
x \\
x\end{array}$ & $\begin{array}{l}0 \\
0 \\
x \\
x\end{array}$ & $x$ & $\times$ & $\begin{array}{l}x \\
\times\end{array}$ & & $\begin{array}{l}\mathrm{P} \\
\mathrm{P} \\
\mathrm{P} \\
\mathrm{P}\end{array}$ & NP 23 \\
\hline $\begin{array}{l}10-2,8 \\
10, \mathrm{CC}\end{array}$ & \multicolumn{17}{|c|}{ Barren } & & $?$ \\
\hline $\begin{array}{l}11-1,3-4 \\
11, \mathrm{CC} \\
12, \mathrm{CC}\end{array}$ & $\begin{array}{l}0 \\
0 \\
\times\end{array}$ & $\begin{array}{l}\stackrel{x}{0} \\
\times\end{array}$ & $\stackrel{x}{0}$ & $\begin{array}{l}0 \\
0\end{array}$ & $\begin{array}{l}0 \\
\times \\
\times\end{array}$ & $\stackrel{x}{0}$ & $\times$ & & $\begin{array}{l}x \\
0 \\
x\end{array}$ & & $\begin{array}{l}x \\
\times\end{array}$ & $\begin{array}{l}\times \\
\dot{0} \\
\times\end{array}$ & 0 & & & $\begin{array}{l}x \\
x\end{array}$ & $\times$ & $\begin{array}{c}\mathrm{P} \\
\mathrm{P}, \mathrm{M}\end{array}$ & NP 23 \\
\hline
\end{tabular}

Note: $X=$ rare to few,$O=$ common, $\bullet=$ abundant. Preservation: $P=$ poor, $M=$ moderate, $G=$ good. (See also Tables $2-4$.)

${ }^{a}$ Reworked species.

Zone) at the top, grading downward into Zone NP 23 (S. predistentus Zone) in both holes. Core 12 of Hole 447A may actually be equivalent to part of Core 6 in Hole 290. At Hole 290 the oldest fossil found seems to date from the late Eocene or early Oligocene, but there is a discrepancy between the nannoplankton and radiolarian age determination (Karig, Ingle, Jr., et al., 1975). In Hole 447A displaced lower Oligocene nannofossils are noted throughout the middle Oligocene section, suggesting a continuous input of eroded material from lower Oligocene sediments. This might well apply to Site 290 also, where continuous mixing with upper Eocene radiolarian clays displaced from a nearby source seems to have occurred.

\section{Site 448 \\ $\left(16^{\circ} 20.46^{\prime} \mathrm{N}, 134^{\circ} 52.45^{\prime} \mathrm{E}\right.$, depth $\left.3483 \mathrm{~m}\right)$}

Hole 448, at the Palau-Kyushu Ridge, provided a continuous sequence from the middle Miocene (Zone NN 9-Discoaster hamatus Zone) to the middle Oligocene (Zone NP 23-Sphenolithus predistentus Zone). (For details and distribution of nannoplankton species in Hole 448, see Table 2.) The youngest basalt flow was encountered in Core 37 (337.5-347.0 m), which, according to the nannofossils, is middle Oligocene (calcareous nannoplankton Zone NP 23). Sediment lenses trapped within or between basalt flows in Cores $40,48,49$, and 51 still contain nannofossils of Zone NP 23. Parts of Cores 20 to $27(176.0-252.0 \mathrm{~m})$ and Cores 36 to 65 (328.0 to the terminal depth of $583.5 \mathrm{~m}$ ), with the exception of the trapped sediments mentioned earlier, are barren of calcareous nannoplankton.
Zones NN 6 (D. exilis Zone) through NN 9 (D. hamatus Zone) are present within Core $1(0-5.0 \mathrm{~m})$. The boundary between Zone NN 7 (D. kugleri Zone) and Zone NN 8 (Catinaster coalitus Zone) was cored twice, probably because of resampling or disturbance of material within the liner. Zone NN 5 (S. heteromorphus Zone) occurs in Cores 2 to the upper part of 4 (5.0 to approximately $30.0 \mathrm{~m}$ ). Because the marker species that designates the top of Zone NN 4-Helicosphaera ampliaperta-is absent in this area, the first occurrence of $D$. exilis is used to identify tentatively the boundary between Zones NN 4 and NN 5 (Martini and Worsley, 1971). The preservation of discoasters at this level, however, is rather poor, and identifications are somewhat questionable. Displaced calcareous nannoplankton also seems to be present at certain levels between Samples 1,CC and 3, CC, given that Orthorhabdus serratus, Triquetrorhabdulus carinatus, and $S$. belemnos are found well above their last occurrences elsewhere (see Table 2). In Sample 5, CC S. ciperoensis and $S$. distentus occur in several specimens in calcareous nannoplankton Zone NN 2 ( $D$. druggi Zone), also indicating the presence of reworked material from older strata at this particular level.

Sample 4, CC is tentatively placed in Zone NN 3 ( $S$. belemnos Zone), although a few specimens of $T$. cf. carinatus were found, but because Core $5(33.5-43.0 \mathrm{~m})$ had a very low recovery rate, this zone might also be present in part of the unrecovered interval of Core 5 . Zone NN 2 ( $D$. druggi Zone) is present in Core 5; and Zone NN 1 ( $T$. carinatus Zone) occurs in Cores 6 to 8 $(43.0-71.5 \mathrm{~m})$. The base of this zone, indicated by the 
Table 2. Distribution of calcareous nannoplankton in selected samples from Hole 448 and an indication of standard nannoplankton zones.

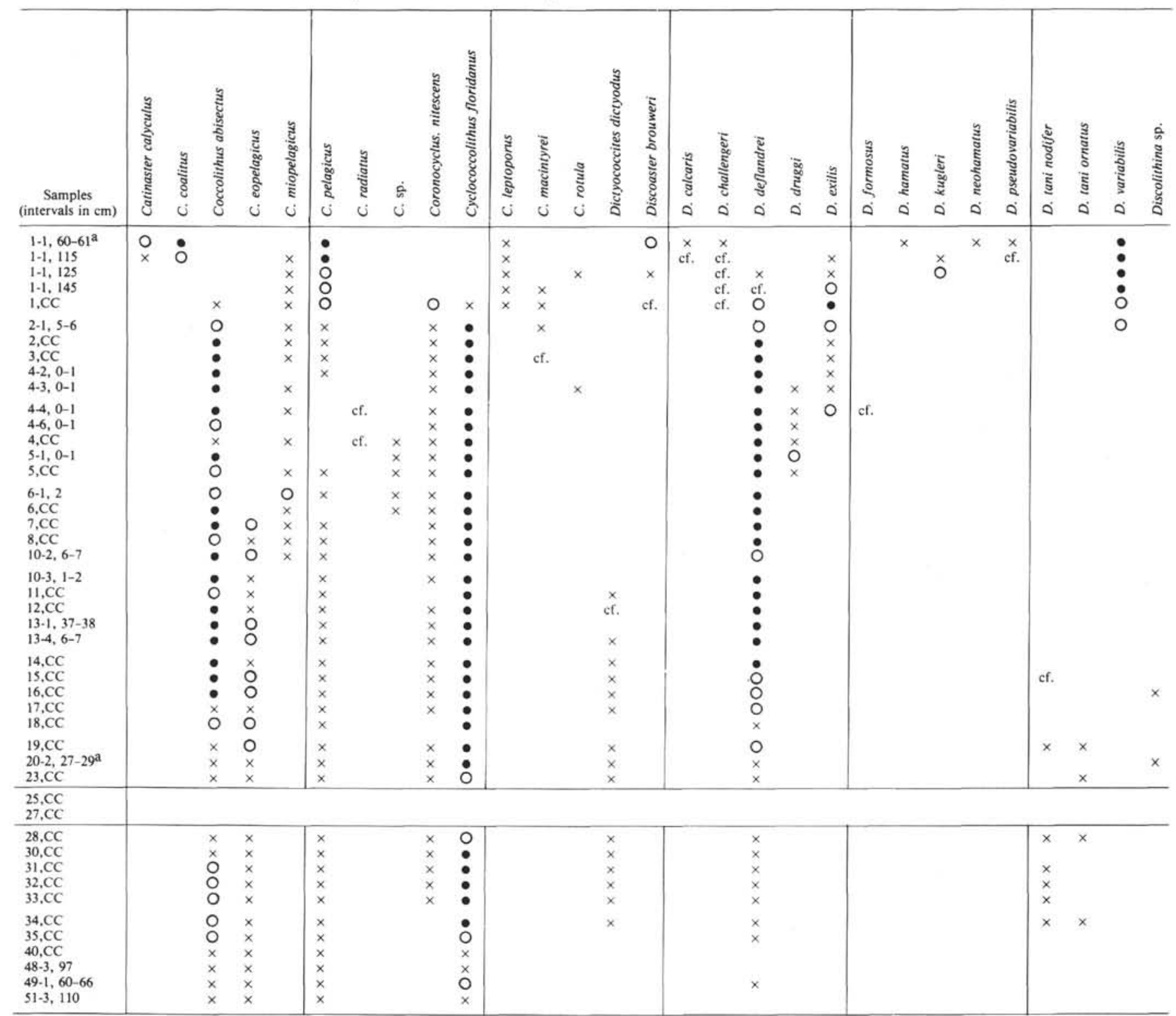

Note: $\mathrm{D}=$ displaced from older strata.

a Scanning electron microscope (SEM)-studied samples.

last occurrence of S. ciperoensis, is taken as the Oligocene/Miocene boundary. Core $9(71.5-81.0 \mathrm{~m})$ had no recovery.

Zone NP 25 (S. ciperoensis Zone) is identified from the top of Core 10 down to Core 12 (approximately 81.0-109.5 m), where the last occurrence of $S$. distentus is noted. As in Site 447 the first specimens of $S$. ciperoensis and Coccolithus abisectus do not occur at the same level. This may be partly due to the high sedimentation rate, which would tend to separate these first occurrences, generally reported at approximately the same chronological level (Müller, 1970). The part that contains $S$. ciperoensis is identified as Zone NP 24 (approximately $109.5-299.5 \mathrm{~m}$ ) and that without $S$. ciperoensis, but still containing C. abisectus, is labelled
NP 23 (below $299.5 \mathrm{~m}$ ). In Section 2 of Core 20 a sudden occurrence of Scyphosphaera species is noted.

Zygrhablithus bijugatus, which has its last occurrence in Sample 10-2, 6-7 cm, is most common in Cores 16 to $18(138.0-166.5 \mathrm{~m})$. This form is also present with changing frequency in cores below that level. $Z$. bijugatus is a neritic species and is commonly found in abundance in "near-shore" environments. Similar occurrences of $Z$. bijugatus were previously reported from the upper Oligocene of the Rockall Plateau (Leg 12, Perch-Nielsen, 1972), Iceland-Faeroe Ridge (Leg 38, Muller, 1976), and Reykjanes Ridge (Leg 49, Martini, 1979); such findings indicate the relatively shallow position of these areas, which can also be postulated for the area around Site 448 during part of the Oligocene. 
Table 2. (Continued).

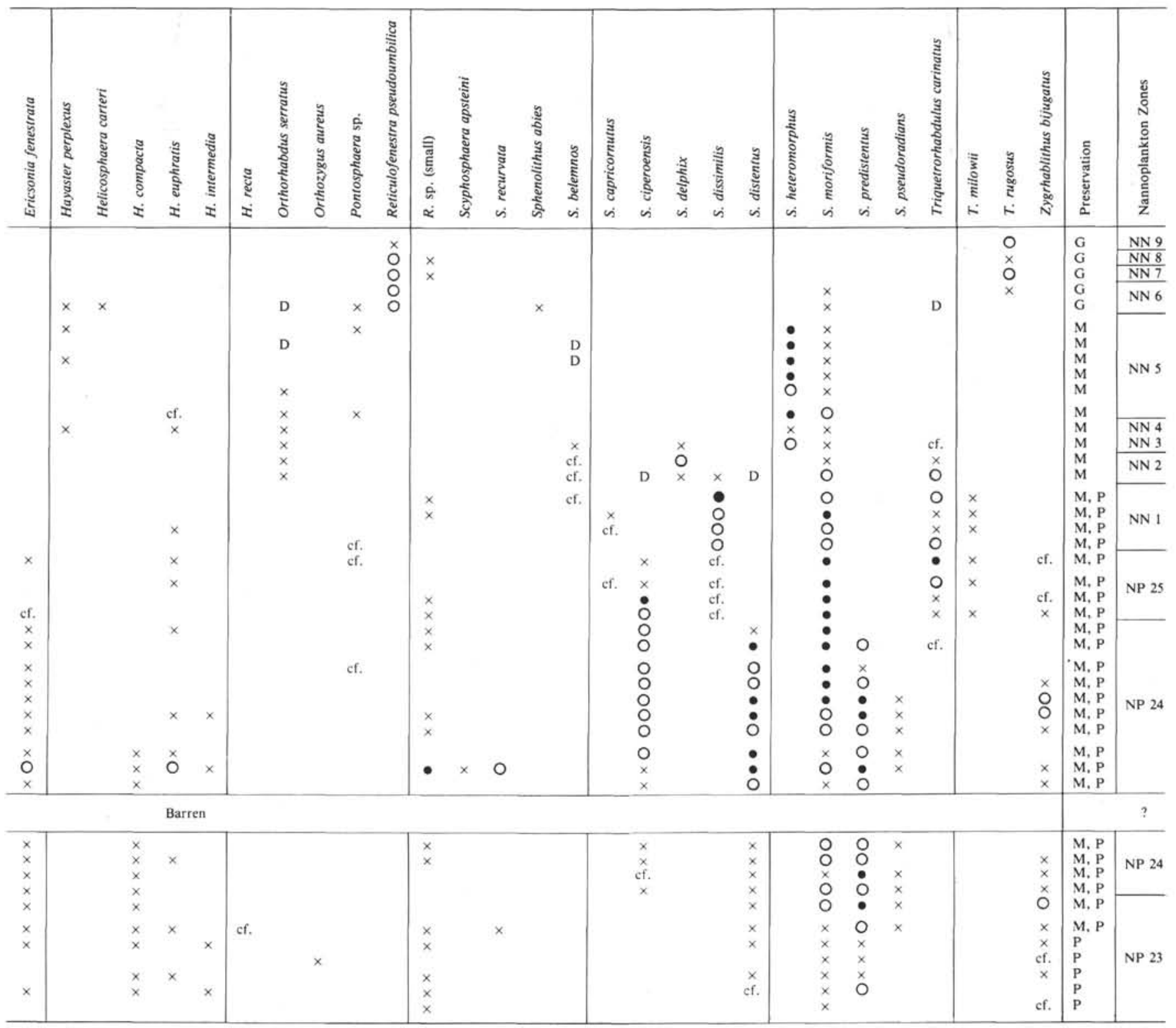

Below the highest basalt flow in Core 37, trapped sediment lenses are found within or between basalt flows in Cores 40,48, 49, and 51 containing calcareous nannoplankton assemblages of Zone NP 23 (S. predistentus Zone).

Preservation of calcareous nannoplankton is fairly good in Core 1; below this, specimens are slightly etched and discoasters are more or less heavily overgrown by calcite, which is also true for $Z$. bijugatus in the Oligocene. Poor preservation is generally noted in the lowest sediment layers as well as in sediments trapped within or between basalt flows.

Again, from a nearby site a Lamont piston core was available for comparison. Core V34-13 $\left(16^{\circ} 12^{\prime} \mathrm{N}, 134^{\circ}\right.$ $44.5^{\prime} \mathrm{E}$, water depth $3325 \mathrm{~m}$ ) has a total length of 384 $\mathrm{cm}$ and contains abundant calcareous nannoplankton.
The assemblages are dominated by discoasters; also Ceratolithus species are fairly common, whereas other genera are almost missing, probably because of dissolution. The lower part of the core (Samples $284 \mathrm{~cm}, 325$ $\mathrm{cm}, 384 \mathrm{~cm}$ ) belongs to Zone NN 11 (Discoaster quinqueramus Zone), with the nominate species especially common in the two lower samples. Samples from $70 \mathrm{~cm}$ $136 \mathrm{~cm}, 145 \mathrm{~cm}$, and $200 \mathrm{~cm}$ may represent the lower Pliocene, as $D$. surculus, $D$. variabilis, and $D$. brouweri are abundant in all samples, but because other genera are missing a precise age determination is not possible. Ceratolithus cristatus and $C$. telesmus present in the higher samples may represent contamination from the uppermost part. The highest sample taken (at $5 \mathrm{~cm}$ ) contains a mixture of fairly well-preserved calcareous nannoplankton of Zone NN 21 (Emiliania huxleyi Zone), 
including the nominate species and a solution-affected, discoaster-enriched nannoplankton assemblage probably of the early Pliocene.

Another Lamont piston core from about the same longitude, but $7^{\circ}$ to the north, was investigated for discoasters by Takayama (1969). In Core V21-98 (23 ${ }^{\circ}$ $06^{\prime} \mathrm{N}$; $134^{\circ} 26^{\prime} \mathrm{E}$, water depth $2134 \mathrm{~m}$ ) abundant $D$. brouweri, $D$. pentaradiatus, and $D$. surculus were found between 210 and $517 \mathrm{~cm}$, indicating the Pliocene (Zone NN 16 or older) for this particular interval. Because coccoliths were not studied at this time, additional data are not available for this core.

\section{Hole 448A}

At Hole $448 \mathrm{~A}$, an attempt was made to recover material from the poorly represented intervals of Hole 448. Core $1(0-5.0 \mathrm{~m})$ contains well-preserved calcareous nannoplankton dominated by discoasters of Zone NN 8 (Catinaster coalitus Zone) at the top through NN 5 (Sphenolithus heteromorphus Zone) at its base. In Hole 448A the level equivalent to Sample 448-5 was successfully sampled in Core $2(33.5-43.0 \mathrm{~m})$, but nannoplankton found belong to the lower Miocene Zone NN 1 (Triquetrorhabdulus carinatus Zone), with the exception of the uppermost part, which can be placed in Zone NN 2 (Discoaster druggi Zone). The Oligocene/ Miocene boundary, as indicated by the calcareous nannoplankton, is between Cores 3 and 4 at a depth of approximately 71.5 meters. Nannoplankton assemblages in samples from the Oligocene Zones NP 25 (Core 4, 71.5-81.0 m), NP 24 (Cores 5 and 6, 223.5-237.0 and 252.0-261.5 m, respectively), and NP 23 (Cores 7 to 9 , $261.5-290.0 \mathrm{~m})$ and in the sediment layers between basalt (Cores 13, 26, 49, and 51) or out of casts in breccias (Core 42) do not differ from those found in Hole 448. The core-catcher material of Core 6 seems to be heavily contaminated by material caved in from uphole. The Zone NP 25 assemblage in the core catcher must be displaced, because a Zone NP 24 assemblage overlies it in Section 3 of Core 6. Sphenoliths with long projections are abundant in the $S$. predistentus-S. distentus-S. ciperoensis group, and this aspect seems to follow a distributional trend. The hole was terminated in basalt at 914.0 meters (Core 66).

\section{Site 449}

\section{$\left(18^{\circ} 01.84^{\prime} \mathrm{N}, 136^{\circ} 32.19^{\prime} \mathrm{E}\right.$, depth $\left.4712 \mathrm{~m}\right)$}

In Hole 449, in the Parece Vela Basin, the cores down to the upper part of Core 6 (approximately $42.5 \mathrm{~m}$ ), as well as the interval between Core 8 and the upper part of Core $10(57.0-83.5 \mathrm{~m})$, are barren of calcareous nannoplankton, with the exception of reworked late Oligocene nannoplankton including Sphenolithus ciperoensis in Core 4. Basalt was encountered in Core 14 at 111.0 meters down to the terminal depth of 151.5 meters.

Discoasters dominate the calcareous nannoplankton assemblage in the lower part of Core 6, which can be placed in the middle Miocene Zone NN 6 (Discoaster exilis Zone). Samples from Core 7 contain rare $S$. heteromorphus, indicating Zone NN 5 (S. heteromor- phus Zone). Calcareous nannoplankton in the lower part of Core 10 and in the upper part of Core 11 are strongly etched, resulting in a selective preservation of shields of only sturdy species and of heavily overgrown discoasters. The poor preservation of this reduced assemblage does not allow a precise age determination, but the lower Miocene Zone NN 3 ( $S$. belemnos Zone) may be represented by part of this interval. Below Core 11 (85.5-95.0 m), assemblages are less affected by dissolution and are well-diversified, especially in the lower Miocene Zones NN 2 ( $D$. druggi Zone)-between Samples 11-6, 10-11 cm and 12-1, 14-15 cm-and NN 1 (Triquetrorhabdulus carinatus Zone)-between Samples $12-2,12-13 \mathrm{~cm}$ and $13-5,14-15 \mathrm{~cm}$. The same applies for the upper Oligocene Zone NP 25 (S. ciperoensis Zone), which is encountered at the base of Core 13 above the basalt. Sphenolith-dominated tropical assemblages are present in Zone NN 1, including S. delphix and $S$. capricornutus. A similar assemblage, but also including $D$. druggi, appears in the core catcher of Core 14 below basalt, representing lower Miocene material caved in from above.

Preservation of the calcareous nannoplankton assemblages indicates a deposition above the CCD in the late Oligocene and earliest Miocene, with a subsequent subsidence of the area below the CCD in the late early Miocene. During a relatively short period in the middle Miocene, deposition took place around the CCD, but was well below it again from the late middle Miocene onward.

\section{Site 450 \\ $\left(18^{\circ} 00.02^{\prime} \mathrm{N}, 140^{\circ} 47.34^{\prime} \mathrm{E}\right.$, depth $\left.4707 \mathrm{~m}\right)$}

The sediments from Hole 450, in the Parece Vela Basin, consist of brown pelagic clay overlying the ashrich sediments. Basalt occurs in Core 36, at 330 meters sub-bottom. (For details and fossil content of the site, see Table 3.)

Cores 1 to $5(0-45.5 \mathrm{~m})$ are barren of calcareous nannoplankton, with the exception of the lowest part of Core 4 and the upper part of Core 5 . Here a poorly to moderately preserved nannoplankton assemblage is present, including Discoaster hamatus, Catinaster calyculus, D. bollii, and common D. calcaris and D. neohamatus. This assemblage seems to belong to Zone NN 9 (D. hamatus Zone). However, the rather common occurrence of $D$. calcaris and $D$. neohamatus may indicate displaced material from Zones NN 9 and NN $10(D$. calcaris Zone) within the unfossiliferous pelagic clay.

From Core 6 downward, calcareous nannoplankton is continuously present. The following middle Miocene zones were identified: NN 9 (D. hamatus Zone) in Core $6(45.5-55.0 \mathrm{~m})$, NN 8 (C. coalitus Zone) in Core 7 and the upper part of Core $8(55.0$ to approximately $66.5 \mathrm{~m})$, NN 7 (D. kugleri Zone) in the lower part of Core 8 down to Core 12 (approximately $66.5-112.0 \mathrm{~m}$ ), NN 6 (Discoaster exilis Zone) in Core 13 to the upper part of Core $18(112.0$ to approximately $163.0 \mathrm{~m})$, and NN 5 (Sphenolithus heteromorphus Zone) in the lower part of Core 18 to the upper part of Core 35 (approximately 163.0 to approximately $324.0 \mathrm{~m}$ ). 
Table 3. Distribution of calcareous nannoplankton in selected samples from Hole 450 and indication of standard nannoplankton zones.

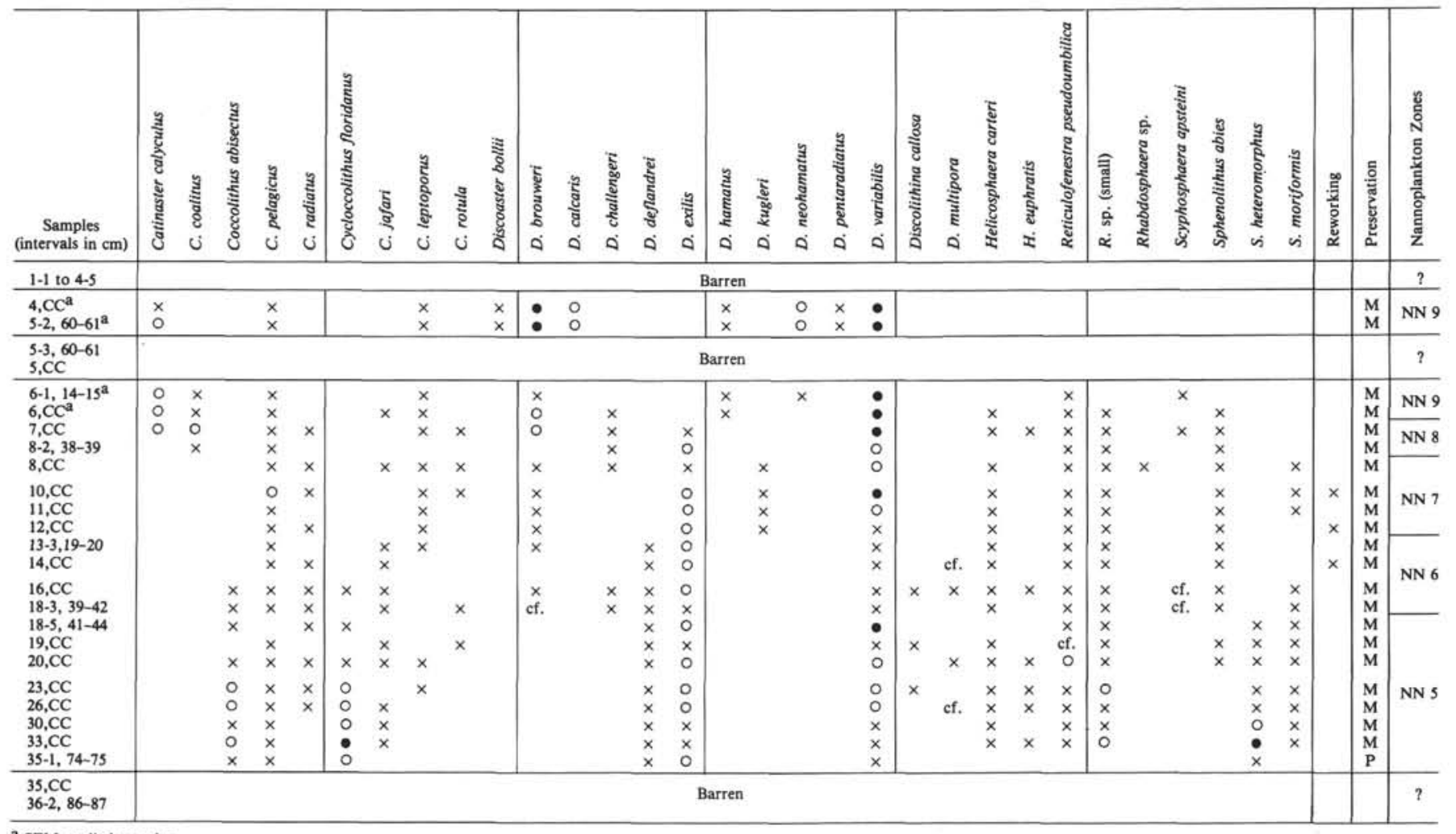

a SEM-studied samples.

Preservation in this sequence is fairly good, with discoasters only slightly overgrown by calcite, probably owing to the high ash content of the sediment. In the lowest part (Cores 34 and 35), however, the calcareous nannofossils are strongly etched and only the more solution-resistant parts are preserved. The lower parts of Cores 35 and 36 are again barren of calcareous nannoplankton.

\section{Site 451}

$\left(18^{\circ} 00.88^{\prime} \mathrm{N}, 143^{\circ} 16.57^{\prime} \mathrm{E}\right.$, depth $\left.2060 \mathrm{~m}\right)$

At Site 451 on the West Mariana Ridge, foraminiferal-nannoplankton ooze is present down to Core 5 $(33.5-43.0 \mathrm{~m})$. Foraminiferal-bearing nannoplankton ooze and marly nannoplankton chalk are found below. These oozes and chalks are interbedded with volcanic ash and vitric tuff, which occur with increasing frequency downhole. Volcanogenic sediments dominate in the lower part of the hole (where biogenic sediments form a minor constituent); a volcaniclastic breccia is present at the terminal depth of 930.5 meters.

In this hole there is a complete succession from the upper Quaternary calcareous nannoplankton Zone NN 21 (Emiliania huxleyi Zone) down to the lower upper Miocene Zone NN 10 (Discoaster calcaris Zone). (For details and distribution of calcareous nannoplankton species in this hole, see Table 4.) At approximately the middle of lithologic Unit 2 (at about $50 \mathrm{~m}$ ), a remarkable change in the accumulation rate from rapid to slow seems to have taken place-if one compares the first oc- currence of Ceratolithus primus with the first and last occurrence of $D$. quinqueramus in this section.

In the part with slow deposition, calcareous nannoplankton Zone NN 21 ( $E$. huxleyi Zone) is present in Sample 1-2, 1-2 cm, with common E. huxleyi identified with the scanning electron microscope. Sample 1-3, 1-2 $\mathrm{cm}$ is placed in Zone NN 20 (Gephyrocapsa oceanica Zone), and Sample 1, CC belongs to Zone NN 19 (Pseudoemiliania lacunosa Zone), as indicated by the presence of $P$. lacunosa in this sample and below. $D$. brouweri was first encountered in Sample 2-4, 8-9 cm and $D$. pentaradiatus in Sample 2-6, 8-9 cm, indicating the presence of Zone NN 18 (D. brouweri Zone) and Zone NN 17 ( $D$. pentaradiatus Zone). The core-catcher sample of Core 2 contains a well-preserved and diversified nannoplankton assemblage, including Umbellosphaera tenuis, besides species listed for Sample 1-2, 1-2 $\mathrm{cm}$ in Table 4. In Sample 3-2, 9-10 cm and below, $D$. surculus was noted and consequently placed together with Sample 3,CC, which is still above the last occurrence of Reticulofenestra pseudoumbilica in Zone NN 16 (D. surculus Zone). Standard nannoplankton Zone NN 15 ( $R$. pseudoumbilica Zone) is present in most of Core 4, which contains common $R$. pseudoumbilica and Sphenolithus abies. The lower part of Core 4 and the uppermost part of Core 5 is placed in the combined Zone NN $13 / 14$, because $D$. asymmetricus was not found (as discussed previously in the nannoplankton zonation section). Sample 5-2, 9-10 cm contains neither $D$. quinqueramus nor C. rugosus; it represents Zone 
Table 4. Distribution of calcareous nannoplankton in selected samples from Hole 451 and indication of standard nannoplankton zones.

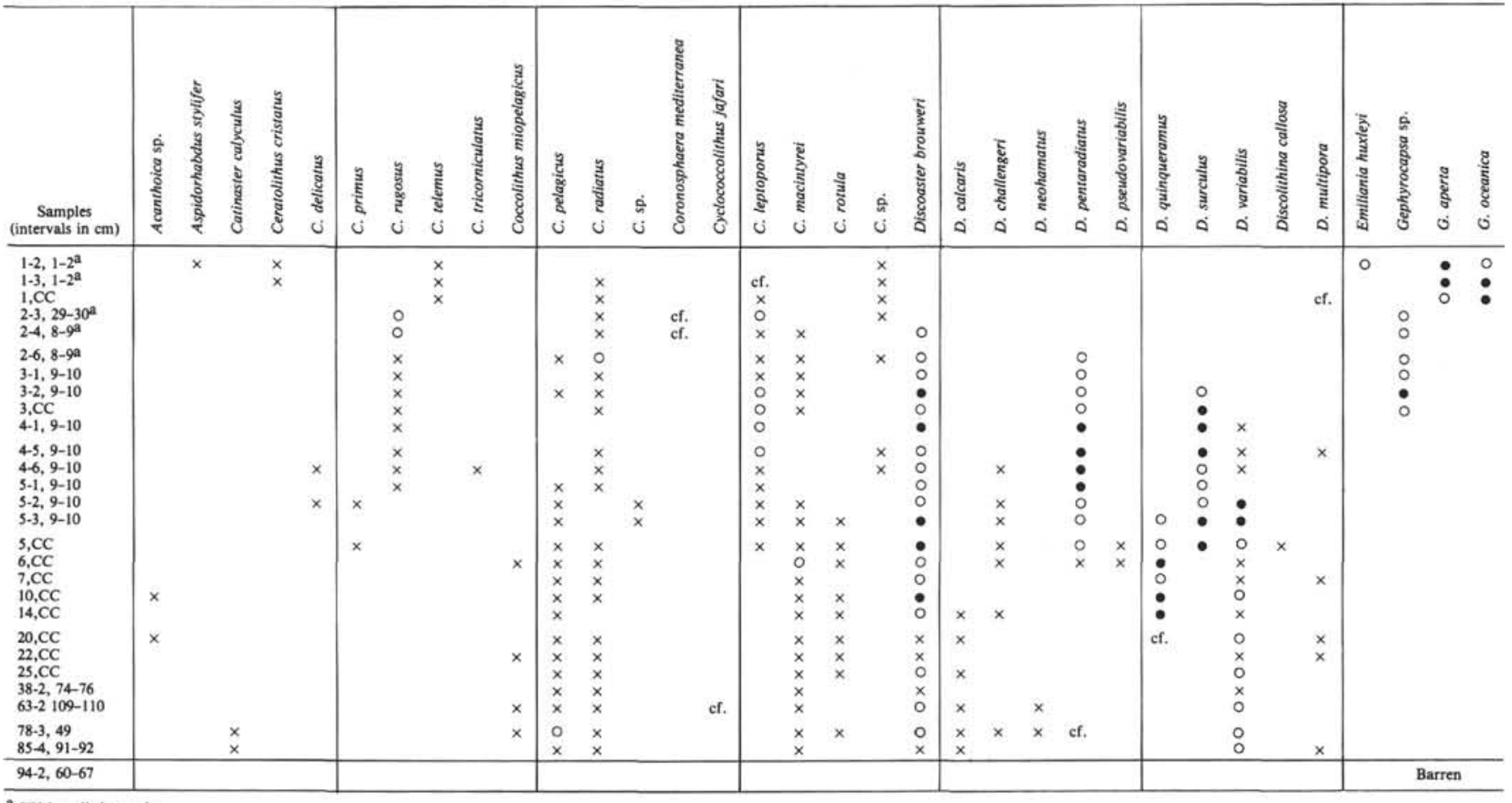

a SEM-studied samples.

NN 12 (C. tricorniculatus Zone), although the nominate species was not found. $D$. quinqueramus is present in Sample 5-3, 9-10 cm and below, indicating the presence of the $D$. quinqueramus Zone (NN 11). The first occurrences of ceratoliths are noted in Sample 5, CC, probably just above the change in the accumulation rate from rapid in the lower part to slow in the upper part of the cored section. The NN 11 assemblage is found from the lower part of Core 5 probably to Core 20 (36.5185.5 meters), although the lower part of this succession is obscured by nonrecovery and barren intervals. In Core 22 and downward to Core 64, several layers contain poorly preserved nannoplankton assemblages, which may belong to Zone NN 10 ( $D$. calcaris Zone), because neither $D$. quinqueramus (first occurrence = base of Zone NN 11) nor D. hamatus (last occurrence = top of Zone NN 9) are found in the volcanogenic sediment. The basal part of Zone NN 10 is reached in Cores 78,80 , and 85 where Catinaster calyculus is present. Some levels contain only solution-resistant forms inadequate for precise age determination.

The preservation of calcareous nannoplankton in Cores 3 to 14 is fair, and it is good in the two uppermost cores, which were also investigated by scanning electron microscope techniques (see samples specified in Table 4). From Core 20 downward, preservation in the nannoplankton-bearing layers is poor, especially in the last fossiliferous Sample 85-4, 91-92 cm.

\section{PERFORATIONS AND ETCHING MARKS}

In a specimen of Hayaster perplexus found in Sample 451-2-1, 43-44 cm (Quaternary, nannoplankton Zone
NN 19), a circular perforation was noted in one of the segments (Plate 4, Fig. 2). Similar perforations have already been referred to in an earlier paper. (Martini, 1976, Plate 10, Figs. 7, 8). In that case the distal shield of a Cyclococcolithus leptoporus specimen, observed in Sample 317-1-1, 5-6 cm (Quaternary, nannoplankton Zone NN 21), was penetrated by two holes. The position and appearance of these holes cannot be correlated to any solution or etching pattern. They were probably caused by bacteria, which seem to be able to penetrate coccoliths as well as other calcareous objects after deposition, as indicated by recent investigations in the Eocene Monte Bolca layered chalks (H. Keupp, personal communication, Erlangen).

Triangular depressions on the surface of specimens of $H$. perplexus, Oolithotus fragilis, and Triquetrorhabdulus rugosus found in Holes 448 (Cores 1 and 2) and 451 (Core 1) seem to represent etching marks. In Hole 451 the interval in which the triangular marks were found on $H$. perplexus and $O$. fragilis belongs to nannoplankton Zones NN 17 to NN 21 (late Pliocene to Recent). The depressions are found only on these species, and although other species are still well preserved, these show secondary growth of calcite with well-developed crystal faces in each segment of shields (Plate 4, Fig. 2). In Hole 448, specimens of $T$. rugosus with these marks (Plate 3, Fig. 12) are found in the uppermost part of Core 1 (Miocene, nannoplankton Zone NN 9), where a solution-affected and discoaster-enriched calcareous nannoplankton assemblage is present. These negative marks as well as those found in $H$. perplexus and $O$. fragilis seem to follow the trigonal symmetry of calcite 
Table 4. (Continued),

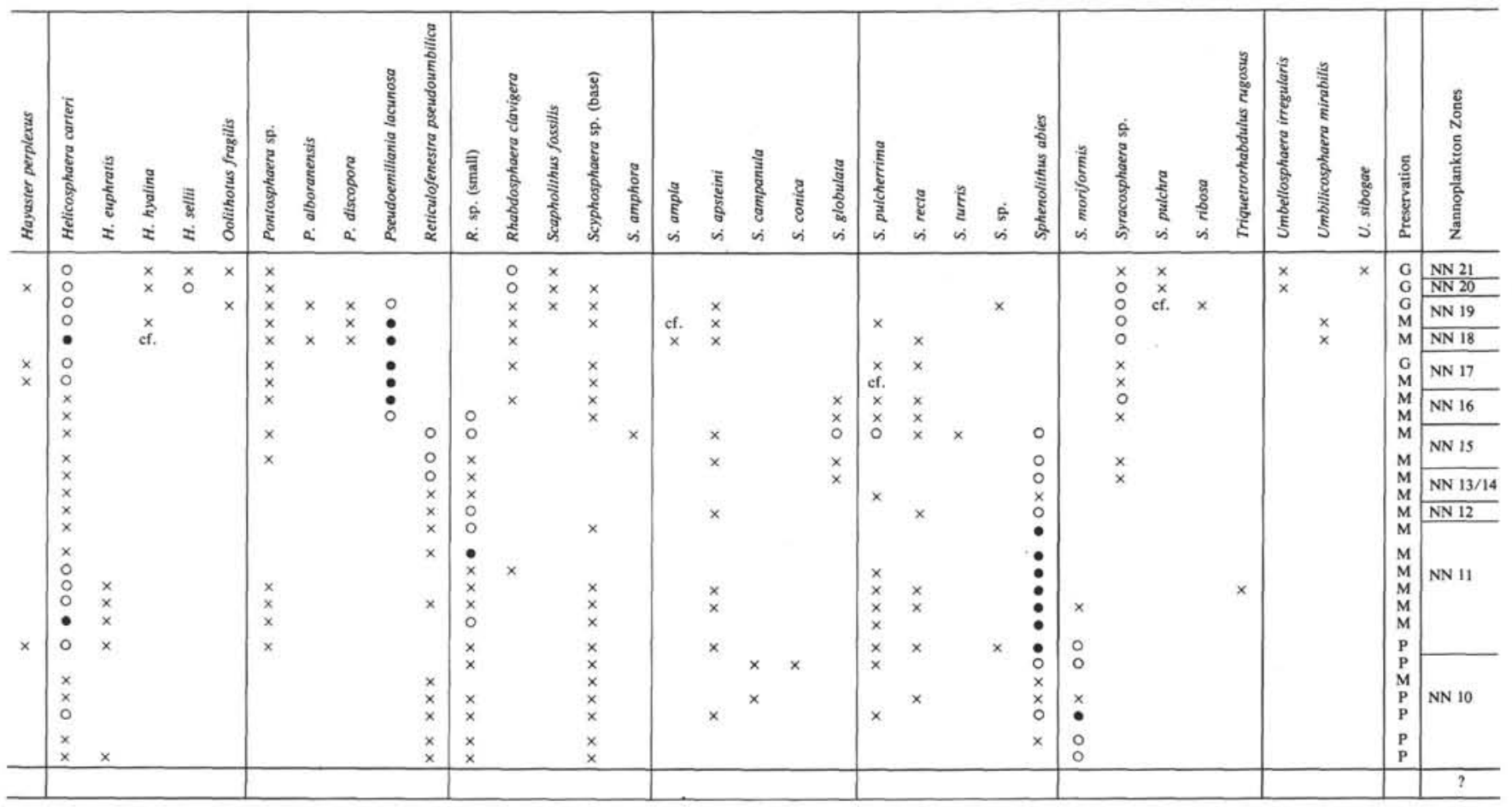

and are aligned in a pattern that agrees with the general orientation of calcite-crystal development in these specimens.

\section{SCYPHOSPHAERA SPECIES IN THE OLIGOCENE}

Scyphosphaera species were reported to occur sporadically in the Eocene by Bramlette and Sullivan (1961), Stradner (1969), and Bukry and Percival (1971). In the Oligocene the genus seems to be fairly rare but was described from Trinidad by Bramlette and Wilcoxon (1967). With the middle Miocene, the genus Scyphosphaera shows a rapid development of different species and was described by various authors (e.g., Jafar, 1975; Rade, 1975) as common and diversified, especially in the upper Miocene and lower Pliocene of many regions. A few species including the long-ranging $S$. apsteini are living in the present oceans.

In the Oligocene part of the Cipero Formation of Trinidad, $S$. apsteini is rare to few in samples from the Sphenolithus predistentus Zone (NP 23), S. distentus Zone (NP 24), and S. ciperoensis Zone (NP 25), according to Bramlette and Wilcoxon (1967) and our own observations. During Leg 59 a sudden occurrence was noted in Core 20 of Hole 448 on the Palau-Kyushu Ridge. In Section 2, in samples between 27 and $29 \mathrm{~cm}$ Scyphosphaera recurvata is common and is associated with a few specimens of $S$. apsteini. The level in which these Scyphosphaera species occur also contains Sphenolithus ciperoensis and S. distentus and accordingly can be placed in Zone NP 24 (S. distentus Zone). Rare Scyphosphaera recurvata are also noted in Sample 448-34, CC, which, on the basis of the nannoplankton assemblage found, belongs in Zone NP 23 (Spheno- lithus predistentus Zone) of the standard nannoplankton zonation. All other occurrences of members of the genus Scyphosphaera found during Leg 59 are from the middle Miocene to late Pliocene interval. As discussed in the foregoing summary of Hole 448, the area around this site may have been in a relatively shallow position during part of the Oligocene, which includes the interval in which the Scyphosphaera species are found. Sphenoliths with long projections are also abundant in several samples of this interval, possibly indicating relatively warm surface waters at that time.

The stratigraphic extension of $S$. recurvata from the Miocene into the middle Oligocene should result in a correction of the phylogenetic lineages within the genus Scyphosphaera published by Rade (1975), because $S$. recurvata occurs much earlier than was formerly known and seems to be closely related to $S$. apsteini rather than originating from $S$. expansa line.

\section{EVOLUTIONARY TRENDS IN THE GENUS CATINASTER}

The genus Catinaster and two species were first described in 1963 by Martini and Bramlette as occurring in the middle Miocene of Trinidad, in the experimental Mohole cores, and in a Lamont piston core. They noted two main features: the relatively short distribution time and partial overlap of the two species; and a certain trend in C. calyculus to increase the length of rays in the upper range of its stratigraphic occurrence. With the initiation of the Deep Sea Drilling Project, more continuous sections became available, and $C$. coalitus was among the species used in the nannoplankton zonation of Bramlette and Wilcoxon (1967), which was later in- 
corporated into the standard nannoplankton zonation (Martini, 1971).

The stratigraphic range of the genus Catinaster seems to be restricted to the middle upper Miocene. The first species to occur is $C$. coalitus, which is designated as the index species to define the base of standard Zone NN 8 (C. coalitus Zone). The genus Catinaster seems closely related to the genus Discoaster, but the link between both is not yet known, although the $D$. musicus group seems to be the best group to look at for such a link. The estimated duration of time for Zone NN 8 is very short and may be only $0.2 \mathrm{~m} . \mathrm{y}$. Within these limits the second important species-C. calyculus-develops from $C$. coalitus, and both are present together in the upper part of Zone NN 8 as well as in most of the following Zone NN 9 (D. hamatus Zone), which probably has a duration of $1 \mathrm{~m} . \mathrm{y}$. The last occurrence of $C$. coalitus, as evidenced by many deep-sea cores, is between the first occurrence of $D$. bollii and the last occurrence of $D$. hamatus, whereas $C$. calyculus reaches into Zone NN 10 (D. calcaris Zone) and has its last occurrence at the same level or shortly above the last occurrence of $D$. bollii.

Bukry (1971b) described another species of the genus Catinaster-from the upper Miocene of DSDP Site 3 in the Gulf of Mexico-as C. mexicanus. More details on the occurrence of this new species were later published by Ellis, Lohman, and Wray (1972); according to their Table 1 it occurs only together with $C$. coalitus. This leaves some doubt about the correct position of Core 9 of DSDP Hole 3 in the stratigraphic column, because it was placed on the basis of a single specimen. This specimen was believed to represent $D$. quinqueramus in the upper part of Zone NN 11 (D. quinqueramus Zone) and in Zone NN 12 (Ceratolithus tricorniculatus Zone) and was found during scanning electron microscope (SEM) studies in Sample 3-9-6, $145 \mathrm{~cm}$. If one could exclude the possibility of displaced older material, this core seems to include Zone NN 8 (Catinaster coalitus Zone) and represents part of the middle Miocene.

Another strange occurrence of C. mexicanus was reported by Müller (1974) from Leg 25 in the western Indian Ocean. In Sample 241-7, CC, this species is quite abundant, but it was not found in any sample uphole or downhole. The sample was placed in the Pliocene Zone NN 15 (Reticulofenestra pseudoumbilica Zone). However, it was stated by Muller that the bifurcation of rays from the outer perimeter seems to be less distinct than Bukry described for the species from DSDP Hole 3. Obviously this species needs some additional and detailed study.

Ellis, Lohman, and Wray in 1972 published an SEM picture (Plate 10, Fig. 1) that seems to indicate that $C$. mexicanus originated from $C$. coalitus. As stated earlier, $C$. calyculus developed from $C$. coalitus by extending the six rays of the distal side beyond their former bifurcation point at the rim of $C$. coalitus (compare Plate 3, Figs. 1, 4, 5). These rays are straight and short in specimens from the lower part of the range of $C$. calyculus. There is a continuous development to long and somewhat curved rays toward the end of the range of this species as shown in Plate 3, Figs. 5, 6, 8, 9 and Plate 5, Figs. 3 to 6 . This trend was consistently observed in several deep-sea cores with a high accumulation rate. Mixture of short- and long-rayed forms may be an indication of a very low accumulation rate or reworking and displacement, as in the lower part of Core 4 and the upper part of Core 5 of Hole 450 (compare site summaries).

The three species included in the genus Catinaster seem to occur in abundance in tropical and subtropical waters, whereas they are missing in high latitudes as well as in the Paratethys. Catinaster? umbrellus Bukry, 1971 , is not thought to belong to the genus Catinaster.

\section{REMARKS ON SELECTED CALCAREOUS \\ NANNOPLANKTON TAXA AND SPECIES}

Most of the calcareous nannoplankton taxa found on Leg 59 are well documented elsewhere and need no discussion. However, a few taxa that commonly are neglected or have to be grouped together because of their small size and that cannot be differentiated by lightmicroscope techniques will be discussed for better understanding, especially of the fossil lists (Tables 1 to 4). Also, two new species that appear in the plates need some explanation.

Genus CERATOLITHUS Kamptner, 1954. Several species of ceratoliths are found in Hole 451 (Table 4). The differentiation into Amaurolithus and Ceratolithus (Gartner and Bukry, 1975) is not. followed here, because there are many transitional forms whose appearance ranges from "dark" to "bright" in polarized light, although there is a general tendency from more "dark" or "semidark" to "bright" appearence in polarized light during the evolution of late Tertiary to Quaternary ceratoliths. On this basis A. delicatus Gartner and Bukry, 1975, is placed into the genus Ceratolithus s.l. and is called C. delicatus (Gartner and Bukry).

Coccolithus radiatus Kamptner, 1955. This species with small to medium-sized placoliths is subcircular to elliptical in shape and seems to range from about the middle Miocene to the Quaternary. Specimens found are identical with those figured by Jafar (1975, Plate 9, Figs. 10, 11, 18).

Coccolithus sp. In Cores 4 to 6 of Hole 448, medium-sized oval forms with a relatively large central area are found, which show an extinction pattern similar to Ericsonia fenestrata (Deflandre and Fert) under crossed nicols (Plate 5, Figs. 7 and 8). The central area is penetrated by a number of pores. This form ranges from the upper part of Zone NN 1 to Zone NN 3.

In Hole 451 , Core 5 another medium-sized oval form with probably two shields is found. It shows weak birefringence and is composed of about 36 segments. The central area is perforated by a few pores. These forms were termed Coccolithus sp. in Table 4 and were found in the uppermost part of Zone NN 11 and in Zone NN 12.

Cyclococcolithus sp. In Hole 451 small circular forms with the general appearance of the genus Cyclococcolithus as seen with the light microscope are listed in Table 4 as Cyclococcolithus sp., although specimens found during SEM studies included also Umbilicosphaera mirabilis and $U$. sibogae (Plate 4, Fig. 12).

Discolithina sp. A few specimens showing the extinction pattern of the genus Discolithina were found in Zone NP 24 of Hole 448, but poor preservation prevented identification of species level.

Discolithina japonica Takayama, 1967. A single specimen not listed in Table 4 was found during SEM studies in Sample 451-2-4, 8-9 cm (upper Pliocene, Zone NN 18) and is shown on Plate 1, Figure 4.

Gephyrocapsa sp. The most common form of the genus Gephyrocapsa has a fused bar that spans the central area close to the long axis. It is identical with those figured by Kamptner (1963) as $G$. aperta. This small species is difficult to identify under the light microscope in some samples because of poor preservation but can be identified under the scanning electron microscope. Forms slightly larger and having a fused bar across the central opening closer to the small axis belong to Gephyrocapsa oceanica (Plate 1, Fig. 6). 
Occurrences of Gephyrocapsa species in the upper Pliocene and lowest Quaternary are listed in Table 4 as Gephyrocapsa sp. because of the above-mentioned difficulties and may also include Coccolithus doronicoides Black and Barnes.

Pontosphaera sp. All forms with single plate and high rim showing the extinction pattern of the genus Pontosphaera found in Holes 448 and 451 , which could not be properly identified through lightmicroscope techniques, are grouped together under Pontosphaera sp. (see Tables 2 and 4 ). In Hole $451 P$. alboranensis and $P$. discopora were identified (Plate 4, Figs. 4 and 5) during SEM investigations of samples from Cores 1 and 2 .

Reticulofenestra sp. Under this name all small Reticulofenestra species that cannot be differentiated with the light microscope are grouped together. Even SEM investigations failed to provide unequivocal criteria for defining species in the present material, because overall preservation is only moderate and central areas poorly preserved.

Scyphosphaera sp. In Samples 451-1, CC, and 20, CC, rare Scyphosphaera specimens are noted that are not complete but seem to have straight walls with an opening larger than the diameter of the base of the lopodolith. In the same hole, occurrences of top or bottom views of various lopodoliths as well as forms with a relatively short rim are found in many samples in the upper Miocene to Quaternary interval and are listed as Scyphosphaera sp. (base) in Table 4.

Syracosphaera sp. Specimens of one or more Syracosphaera species are found in the Pliocene and Quaternary of Site 451. They were identified by their typical extinction pattern under crossed nicols but because of their otherwise small size and weak appearance under the light microscope could not be specifically identified. Some of the specimens found during SEM studies are figured on Plates 1 and 4 and are identified as S. pulchra Lohmann. Not figured but also found during SEM studies is S. ribosa (Table 4). Coronosphaera cf. mediterranea (Plate 4, Fig. 1) is probably among forms listed as Syracosphaera sp. in case samples were only studied by light-microscope techniques.

\section{Family CALCIOSOLENIACEAE Kamptner, 1927 Genus CALCIOSOLENIA Gran in Murray and Hjort, 1912 Calciosolenia compacta new species (Plate 4, Fig. 8 and Plate 5, Fig. 1)}

Holotype. SM.B 13025, Plate 4, Figure 8.

Description. Scapholiths are composed of a rather fragile rhomboid rim with a groove running along the outer sides (Plate 5, Fig. 1). The central area is covered by a small number of laths of different size. The laths of one side overlap the laths of the other side considerably (Plate 4, Fig. 8).

Size. Length $3.5 \mu \mathrm{m}$, width $2.0 \mu \mathrm{m}$.

Remarks. The Recent Calciosolenia tenuis introduced by Lecal (1960) may be related but is too poorly documented to give any decent data for comparison.

Type locality. Sample 451-2-4, 8-9 cm, upper Pliocene, Discoaster brouweri Zone (NN 18).

Distribution. Few in Sample 451-2-4, 8-9 cm, West Mariana Ridge, upper Pliocene (NN 18).

\section{Family RHABDOSPHAERACEAE Lemmermann, 1908 Genus BRAMLETTEIUS Gartner, 1969 Bramletteius? duoalatus new species (Plate 4, Fig. 9)}

Holotype. SM.B 13026, Plate 4, Figure 9.

Description. Elliptical placolith-like base probably constructed of two cycles of calcite elements closely appressed, with the proximal slightly smaller than the distal cycle. Two paddle-shaped structures extend on the distal side, the shaft being shorter and thinner than the blade of each structure. The upper $3 / 5$ of the structures are in contact with each other, divided by only a small fissure. At the distal end the complex is about twice as wide as at its base.

Size. Diameter of basal plate $2 \mu \mathrm{m}$, total height $4.5 \mu \mathrm{m}$.

Remarks. This species is quite unique in the Neogene nannoplankton assemblages and is tentatively assigned to the genus Bramletteius, which includes the only comparable species (B. serraculoides Gartner, 1969) with a similar structure on the distal side of the basal plate. More material is needed to decide on the systematic position of the new species.

Type locality. Sample 451-2-6, 8-9 cm, upper Pliocene, Discoaster pentaradiatus Zone (NN 17).

Distribution. Rare in Sample 451-2-6, 8-9 cm, West Mariana Ridge, upper Pliocene (NN 17).

Table 5 lists the species from the Oligocene to Recent interval that are discussed in this chapter and included in the fossil lists (Tables 1-4) or presented in the plates.

\section{ACKNOWLEDGMENTS}

Thanks are due to the Deutsche Forschungsgemeinschaft for supporting the present study. SEM pictures were taken by J. Tochtenhagen with a Stereoscan Mark 2, which was provided to the Geologisch-Paläontologisches Institut der Universität Frankfurt am Main by the VW-Stiftung. Miss Anne Hossenfelder assembled the data for Tables 1 to 4. My thanks also go to Dr. Carla Müller (Paris) and Dr. Pavel Cepek (Hannover) for reviewing this paper. Type specimens of the two new species are deposited in the Naturmuseum und Forschungsinstitut Senckenberg, Frankfurt am Main, Germany, Catalogue Nos. SM.B 13025 and 13026.

\section{REFERENCES}

Bramlette, M. N., and Sullivan, F. R., 1961. Coccolithophorids and related nannoplankton of the early Tertiary in California. Micropaleontology, 7:129-188.

Bramlette, M. N., and Wilcoxon, J. A., 1967. Middle Tertiary calcareous nannoplankton of the Cipero section, Trinidad, W.I. Tulane Stud. Geol. Paleontol., 5:93-131.

Bukry, D., 1971a. Coccolith stratigraphy Leg 6, Deep Sea Drilling Project. In Fisher, A. G., Heezen, B. C., et al., Init. Repts. DSDP, 6: Washington (U.S. Govt. Printing Office), 965-1004. 1971b. Discoaster evolutionary trends. Micropaleontology, $17: 43-52$.

1973. Low-latitude coccolith biostratigraphic zonation. In Edgar, N. T., Saunders, J. B., et al., Init. Repts. DSDP, 15: Washington (U.S. Govt. Printing Office), 685-703.

Bukry, D., and Percival, S. F., 1971. New Tertiary calcareous nannofossils. Tulane Stud. Geol. Paleontol., 8:123-146.

Ellis, C. H., 1975. Calcareous nannofossil biostratigraphy-Leg 31, DSDP. In Karig, D. E., Ingle, J. C., Jr., et al., Init. Repts. DSDP, 31: Washington (U.S. Govt. Printing Office), 655-676.

Ellis, C. H., Lohman, W. H., and Wray, J. L., 1972. Upper Cenozoic calcareous nannofossils from the Gulf of Mexico (Deep Sea Drilling Project, Leg 1, Site 3). Q. Colo. Sch. Mines, 67 (3):1-103.

Gartner, S., and Bukry, D., 1975. Morphology and phylogeny of the Coccolithophycean family Ceratolithaceae. U.S. Geol. Surv. J. Res., 3:451-465.

Jafar, S. A., 1975. Calcareous nannoplankton from the Miocene of Rotti, Indonesia. Verh. K. Ned. Akad. Wet. Afd. Natuurkd. Reeks 1, 28:1-99.

Karig, D. E., Ingle, J. C., Jr., et al., 1975. Init. Repts. DSDP, 31: Washington (U.S. Govt. Printing Office).

Lecal, J., and Bernheim, A., 1960. Microstructure du squelette de quelques Coccolithophorides. Bull. Soc. Hist. Nat. Afr. Nord., 51:273-297.

Martini, E., 1971. Standard Tertiary and Quaternary calcareous nannoplankton zonation. Proc. II. Planktonic Conf., Roma, 1970, 2:739-785.

1976. Cretaceous to Recent calcareous nannoplankton from the Central Pacific Ocean (DSDP Leg 33). In Schlanger, S. O., Jackson, E. D., et al., Init. Repts. DSDP, 33: Washington (U.S. Govt. Printing Office), 383-423.

1979. Calcareous nannoplankton and silicoflagellates biostratigraphy at Reykjanes Ridge, northeastern North Atlantic (DSDP Leg 49, Sites 407 and 409). In Luyendyk, B. P., Cann, J. R., et al., Init. Repts. DSDP, 49: Washington (U.S. Govt. Printing Office), 533-549.

Martini, E., and Bramlette, M. N., 1963. Calcareous nannoplankton from the experimental Mohole drilling. J. Paleontol., 37:845856. 
Martini, E., and Worsley, T., 1971. Tertiary calcareous nannoplankton from the Western Equatorial Pacific. In Winterer, E. L. Riedel, W. R., et al., Init. Repts. DSDP, 7, Pt. 2: Washington (U.S. Govt. Printing Office), 1471-1507.

Müller, C., 1970. Nannoplankton aus dem Mittel-Oligozan von Norddeutschland und Belgien. Neues Jahrb. Geol. Palaeontol., Abh., , 135:82-101.

1974. Calcareous nannoplankton, Leg 25 (Western Indian Ocean). In Simpson, E. S. W., Schlich, R., et al., Init. Repts. DSDP, 25: Washington (U.S. Govt. Printing Office), 579-633.

1976. Tertiary and Quaternary calcareous nannoplankton in the Norwegian-Greenland Sea, DSDP, Leg 38. In Talwani, M., Udintsev, G., et al., Init. Repts. DSDP, 38: Washington (U. S. Govt. Printing Office), 823-841.
Perch-Nielsen, K. 1972. Remarks on late Cretaceous to Pleistocene coccoliths from the North Atlantic. In Laughton, A. S., Berggren, W. A., et al., Init. Repts. DSDP, 12: Washington (U.S. Govt. Printing Office), 1003-1069.

Rade, J., 1975. Scyphosphaera evolutionary trends with special reference to eastern Australia. Micropaleontology, 21:151-164.

Stradner, H., 1969. The nannofossils of the Eocene flysch in the Hagenbach Valley (Northern Vienna Woods), Austria. Rocz. Pol. Tow. Geol., 39:403-432.

Takayama, T., 1969. Discoasters from the Lamont Core V21-98 (Preliminary reports of the Philippine Sea cores, Part 2). Bull. Nat. Sci. Mus. Tokyo, 12:431-450.

Table 5. Oligocene to Recent calcareous nannoplankton from the Philippine Sea, DSDP, Leg 59.

\section{Acanthoica sp.}

Aspidorhabdus stylifer (Lohmann) Boudreaux and Hay, 1969

Braarudosphaera bigelowi (Gran and Braarud) Deflandre, 1947

Catinaster calyculus Martini and Bramlette, 1963

Catinaster coalitus Martini and Bramlette, 1963

Ceratolithus cristatus Kamptner, 1954

Ceratolithus delicatus (Gartner and Bukry) nov. comb.

Ceratolithus primus Bukry and Percival, 1971

Ceratolithus rugosus Bukry and Bramlette, 1968

Ceratolithus telemus Norris, 1965

Ceratolithus tricorniculatus Gartner, 1967

Coccolithus abisectus Müller, 1970

Coccolithus eopelagicus (Bramlette and Riedel) Bramlette and Sullivan, 1961

Coccolithus miopelagicus Bukry, 1971

Coccolithus pelagicus (Wallich) Schiller, 1930

Coccolithus radiatus Kamptner, 1955

Coccolithus sp.

Coronocyclus nitescens (Kamptner) Bramlette and Wilcoxon, 1967

Coronosphaera mediterranea (Lohmann) Gaarder, 1977

Cyclococcolithus floridanus (Roth and Hay) Müller, 1970

Cyclococcolithus formosus Kamptner, 1963

Cyclococcolithus jafari, see Umbilicosphaera jafari Müller, 1974

Cyclococcolithus leptoporus (Murray and Blackman) Kamptner, 1954, ex 1956

Cyclococcolithus macintyrei Bukry and Bramlette, 1969

Cyclococcolithus rotula (Kamptner) Kamptner, 1956

Cyclococcolithus sp.

Dictyococcites dictyodus (Deflandre and Fert) Martini, 1969

Discoaster bollii Martini and Bramlette, 1963

Discoaster brouweri Tan Sin Hok, 1927

Discoaster calcaris Gartner, 1967

Discoaster challengeri Bramlette and Riedel, 1954

Discoaster deflandrei Bramlette and Riedel, 1954

Discoaster druggi Bramlette and Wilcoxon, 1967

Discoaster exilis Martini and Bramlette, 1963

Discoaster formosus Martini and Worsley, 1971

Discoaster hamatus Martini and Bramlette, 1963

Discoaster kugleri Martini and Bramlette, 1963

Discoaster neohamatus Bukry and Bramlette, 1969

Discoaster pentaradiatus Tan Sin Hok, 1927

Discoaster pseudovariabilis Martini and Worsley, 1971

Discoaster quinqueramus Gartner, 1969

Discoaster surculus Martini and Bramlette, 1963

Discoaster tani Bramlette and Riedel, 1954

Discoaster tani nodifer Bramlette and Riedel, 1954

Discoaster tani ornatus Bramlette and Wilcoxon, 1967

Discoaster variabilis Martini and Bramlette, 1963

Discolithina callosa Martini, 1969

Discolithina japonica Takayama, 1967

Discolithina multipora (Kamptner ex Deflandre) Martini, 1965

Discolithina sp.

Emiliania huxleyi (Lohmann) Hay and Mohler, 1967

Ericsonia fenestrata (Deflandre and Fert) Stradner, 1968

Gephyrocapsa sp.

Gephyrocapsa aperta Kamptner, 1963

Gephyrocapsa oceanica Kamptner, 1943

Hayaster perplexus (Bramlette and Riedel) Bukry, 1973
Helicosphaera carteri (Wallich) Kamptner, 1954

Helicosphaera compacta Bramlette and Wilcoxon, 1967

Helicosphaera euphratis Haq, 1966

Helicosphaera hyalina Gaarder, 1970

Helicosphaera intermedia Martini, 1965

Helicosphaera recta (Haq) Jafar and Martini, 1975

Helicosphaera sellii (Bukry and Bramlette) Jafar and Martini, 1975

Oolithotus fragilis (Lohman) Martini and Müller, 1972

Orthorhabdus serratus Bramlette and Wilcoxon, 1967

Orthozygus aureus (Stradner) Bramlette and Wilcoxon, 1967

Pontosphaera sp.

Pontosphaera alboranensis Bartolini, 1970

Pontosphaera discopora Schiller, 1925

Pseudoemiliania lacunosa (Kamptner) Gartner, 1969

Reticulofenestra pseudoumbilica (Gartner) Gartner, 1969

Reticulofenestra sp. (small)

Reticulofenestra umbilica (Levin) Martini and Ritzkowski, 1968

Rhabdosphaera clavigera Murray and Blackman, 1898

Rhabdosphaera sp.

Scapholithus fossilis Deflandre, 1954

Scyphosphaera sp. (base)

Scyphosphaera ampla Kamptner, 1955

Scyphosphaera amphora Deflandre, 1942

Scyphosphaera apsteini Lohmann, 1902

Scyphosphaera campanula Deflandre, 1942

Scyphosphaera conica Kamptner, 1955

Scyphosphaera globulata Bukry and Percival, 1971

Scyphosphaera pulcherrima Deflandre, 1942

Scyphosphaera recta (Deflandre) Kamptner, 1955

Scyphosphaera recurvata Deflandre, 1942

Scyphosphaera turris Kamptner, 1955

Scyphosphaera sp.

Sphenolithus abies Deflandre, 1954

Sphenolithus belemnos Bramlette and Wilcoxon, 1967

Sphenolithus capricornutus Bukry and Percival, 1971

Sphenolithus ciperoensis Bramlette and Wilcoxon, 1967

Sphenolithus delphix Bukry, 1973

Sphenolithus dissimilis Bukry and Percival, 1971

Sphenolithus distentus (Martini) Bramlette and Wilcoxon, 1967

Sphenolithus heteromorphus Deflandre, 1953

Sphenolithus moriformis (Brönnimann and Stradner)

Bramlette and Wilcoxon, 1967

Sphenolithus predistentus Bramlette and Wilcoxon, 1967

Sphenolithus pseudoradians Bramlette and Wilcoxon, 1967

Syracosphaera sp.

Syracosphaera pulchra Lohmann, 1902

Syracosphaera ribosa (Kamptner) Borsetti and Cati, 1972

Triquetrorhabdulus carinatus Martini, 1965

Triquetrorhabdulus milowii Bukry, 1971

Triquetrorhabdulus rugosus Bramlette and Wilcoxon, 1967

Umbellosphaera irregularis Paasche, 1955

Umbellosphaera tenuis (Kamptner) Paasche, 1955

Umbilicosphaera jafari Müller, 1974

Umbilicosphaera mirabilis Lohmann, 1902

Umbilicosphaera sibogae (Weber van Bosse) Gaarder, 1970

Zygrhablithus bijugatus (Deflandre) Deflandre, 1959 


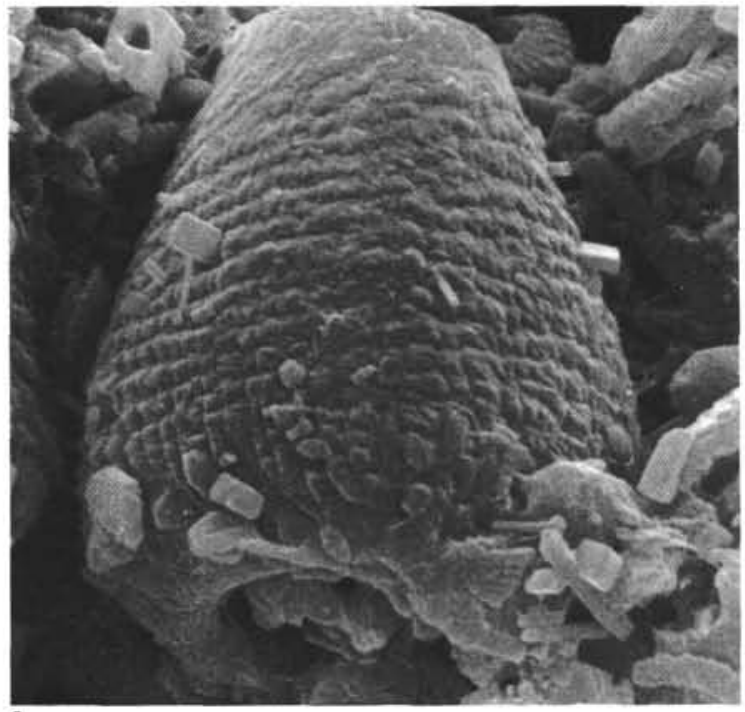

1

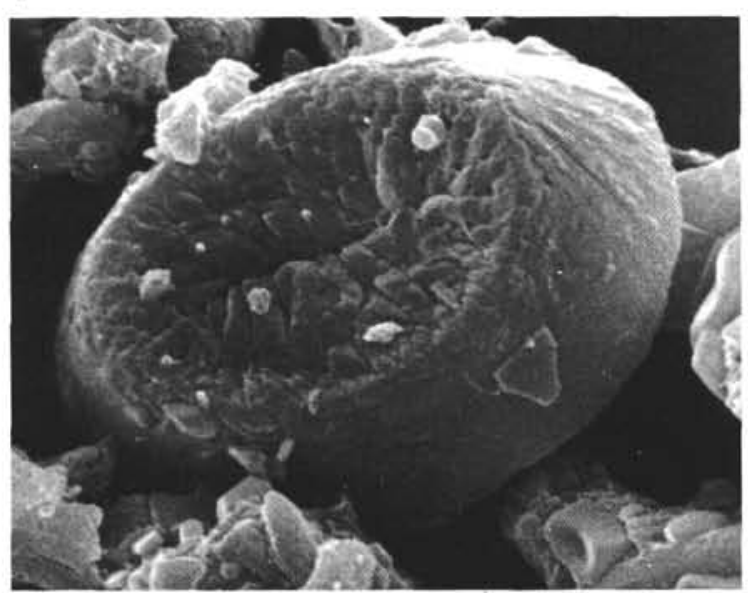

3

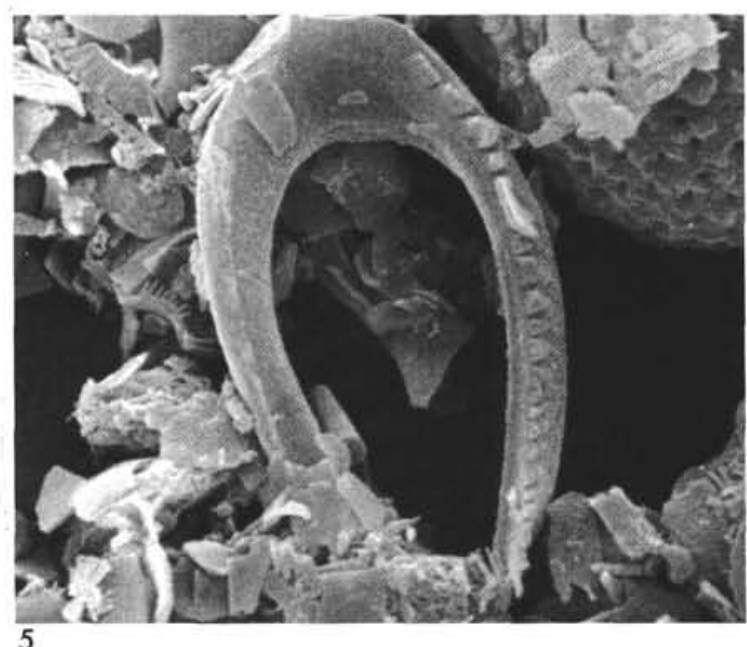

5
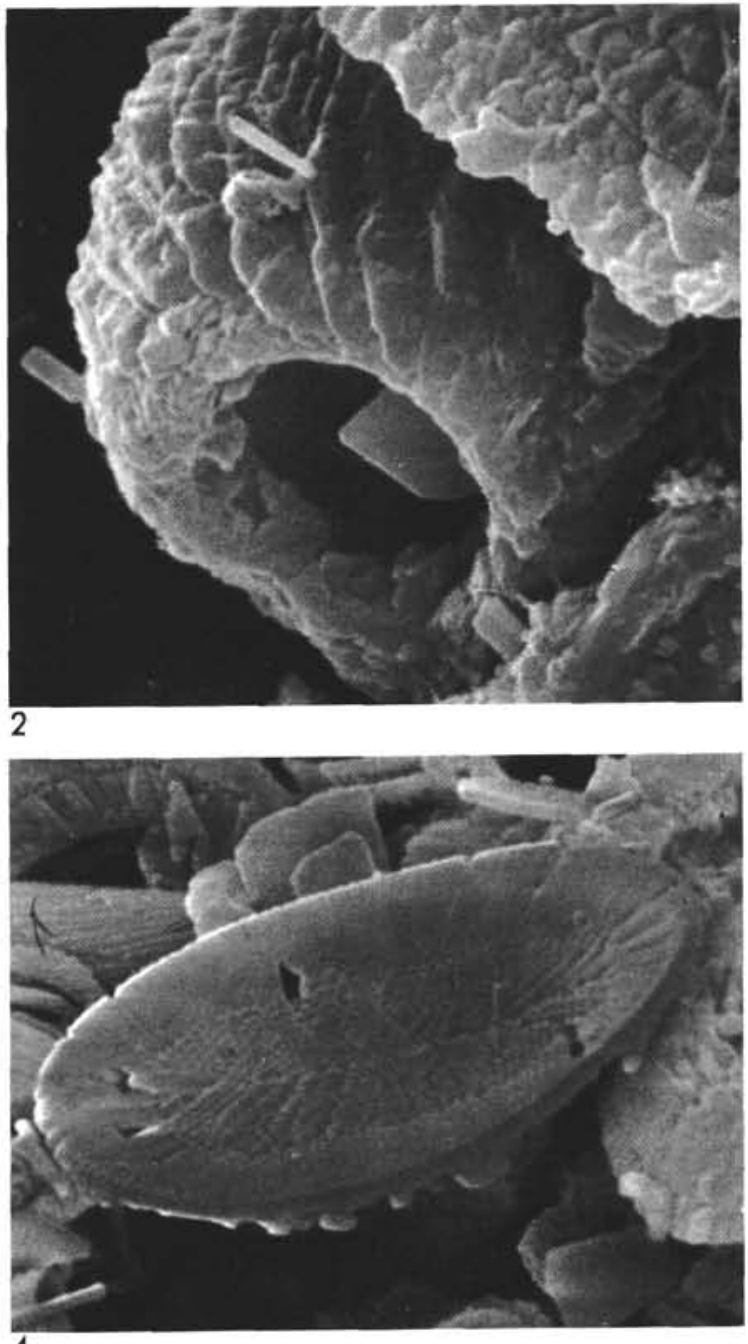

4

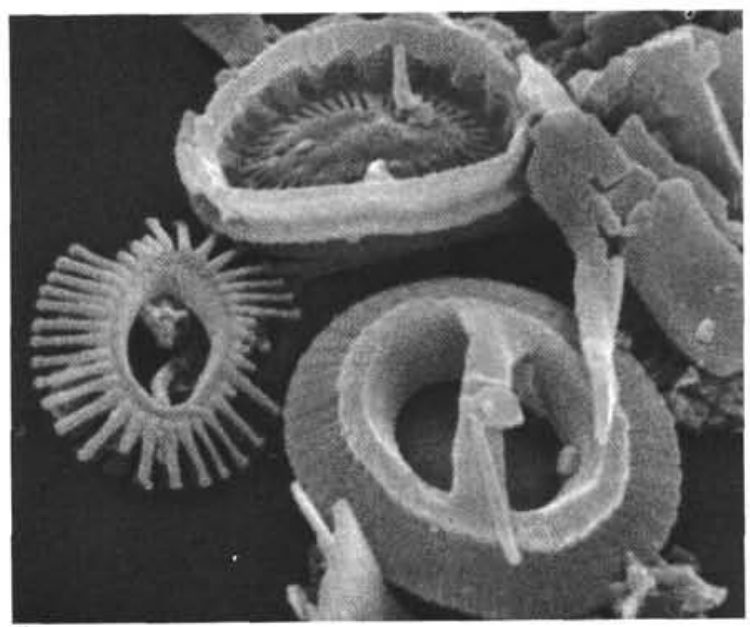

6

Figure 4. Discolithina japonica Takayama, 1967. $\times 9000$, proximal side. Sample 451-2-4, 8-9 cm. Upper Pliocene, Zone NN 18

Figure 5. Ceratolithus cristatus Kamptner, 1954. $\times 9000$. Sample 51-2,CC. Quaternary, Zone NN 21.

Figure 6. Syracosphaera pulchra Lohmann, 1902. Emiliania huxleyi (Lohmann) Hay and Mohler, 1967. Gephyrocapsa oceanica Kamptner, 1943. $\times 9000$, distal sides. Sample 451-2,CC. Quaternary, Zone NN 21. 


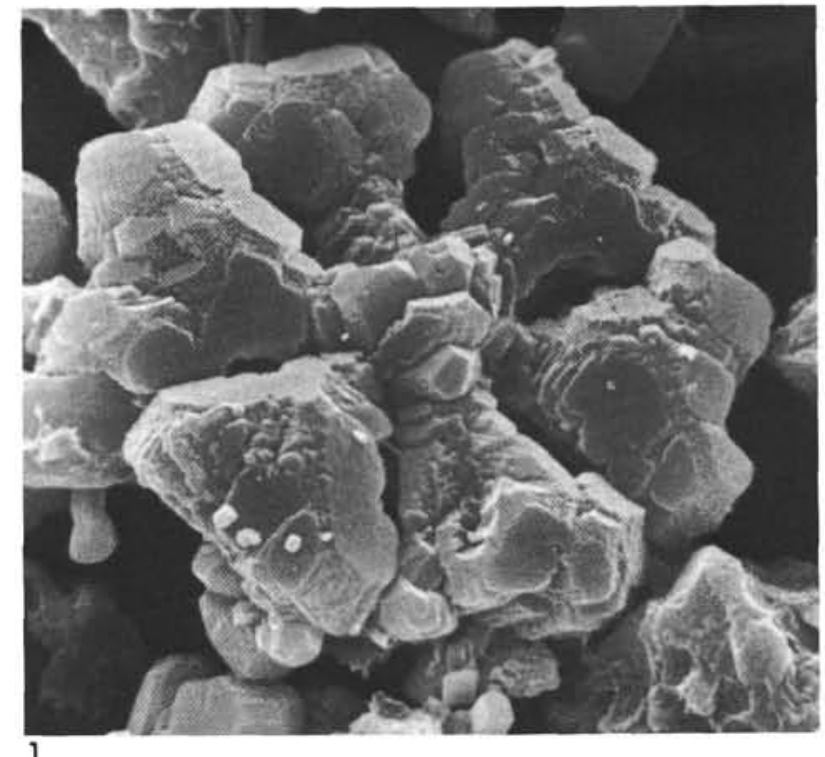

1

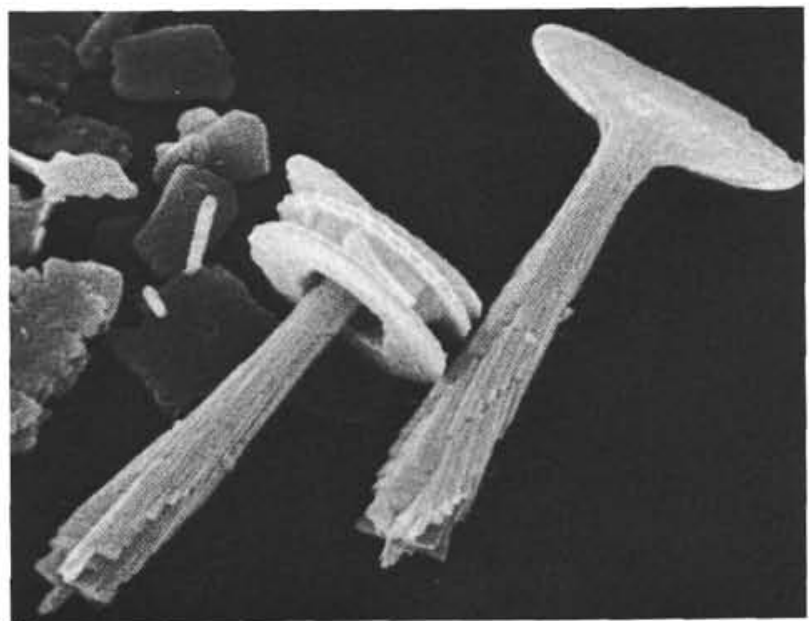

3

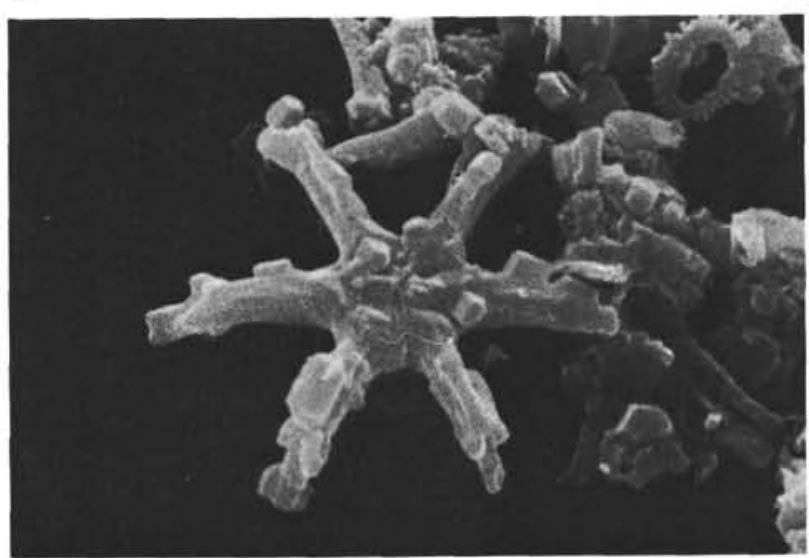

5

Plate 2. Oligocene to Quaternary calcareous nannoplankton.

Figure 1. Discoaster variabilis Martini and Bramlette, 1963. Heavily overcalcified specimen with well-developed crystal faces on rays. $\times 5000$. Sample 450-8-1, 38-39 cm. Middle Miocene, Zone NN 8.

Figure 2. Discoaster calcaris Gartner, 1967. Aberrant six-rayed specimen. $\times 5000$, convex side. Sample 448-1-1, 8-9 cm. Miocene, Zone NN 9.

Figure 3. Rhabdosphaera clavigera Murray and Blackman, 1898. $\times 7500$, side views. Sample 451-2,CC. Quaternary, Zone NN 21 .

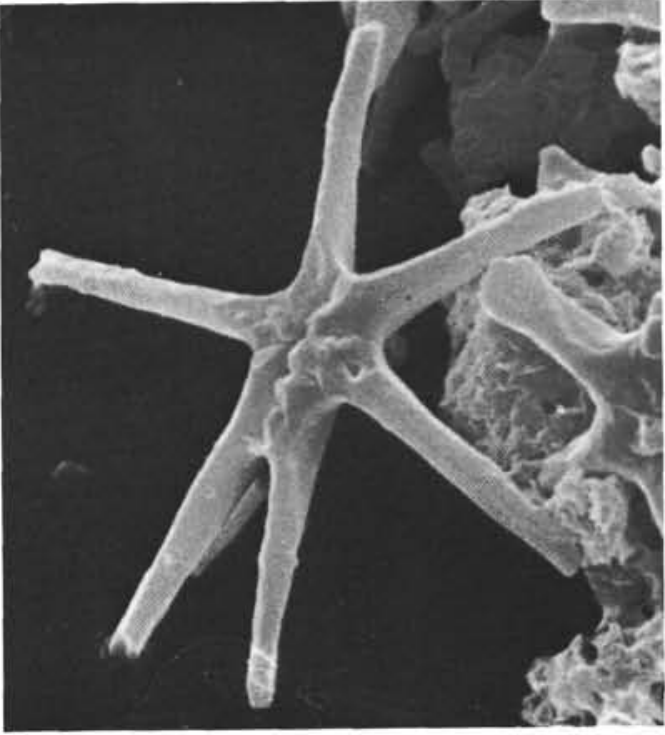

2
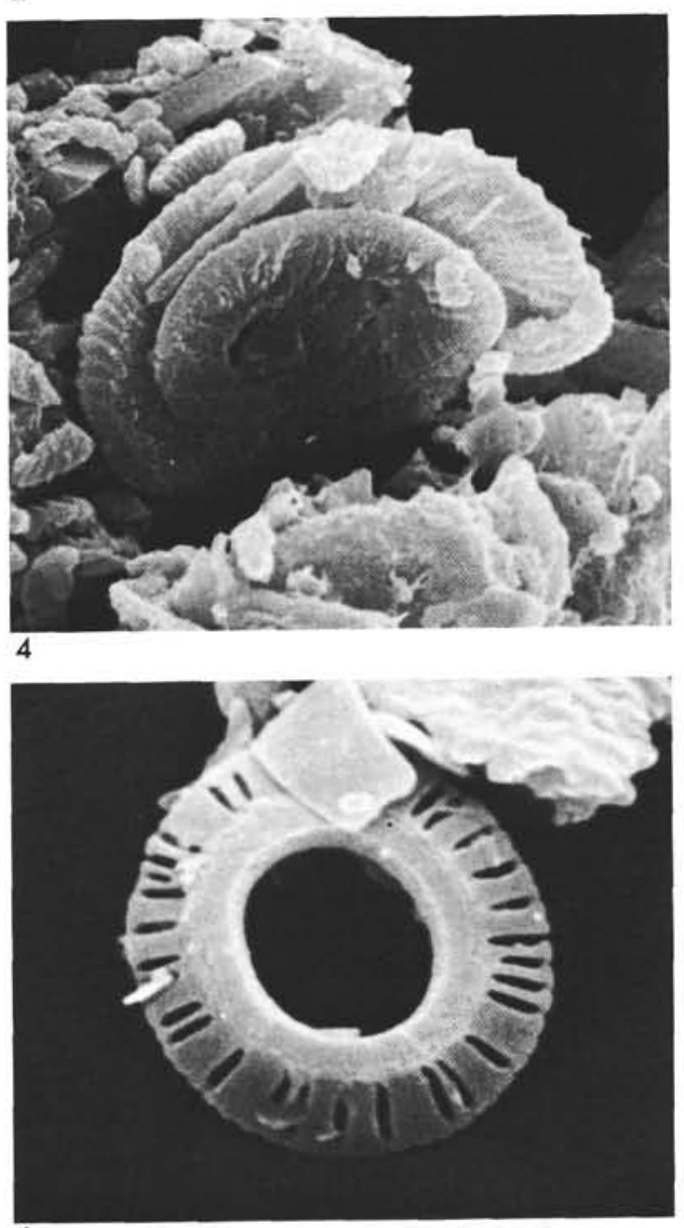

6

Figure 4. Helicosphaera euphratis Haq, 1966. $\times 5000$, proximal side. Sample 448-20-2, 27-28 cm. Oligocene, Zone NP 24.

Figure 5. Discoaster surculus Martini and Bramlette, 1963. Six-rayed specimen with some secondary growth of calcite. $\times 5000$, convex side. Sample V34-13, $5 \mathrm{~cm}$. Pliocene (Zone NN 16?) with Quaternary admixture (Zone NN 21).

Figure 6. Pseudoemiliania lacunosa (Kamptner) Gartner, 1969. $\times 10,000$, distal side. Sample 451-2-2, 68-69 cm. Quaternary, Zone NN 19. 

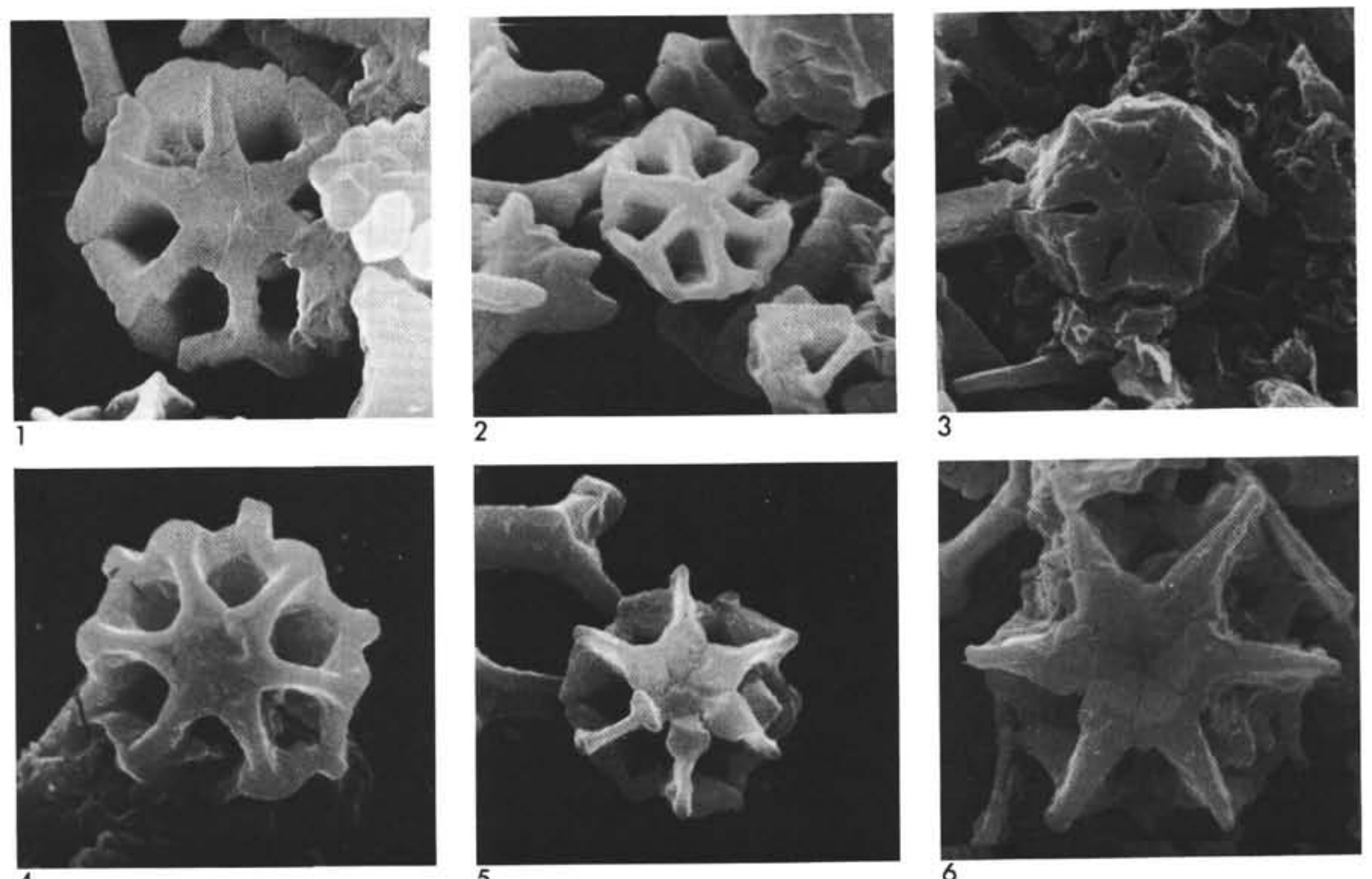

5

6
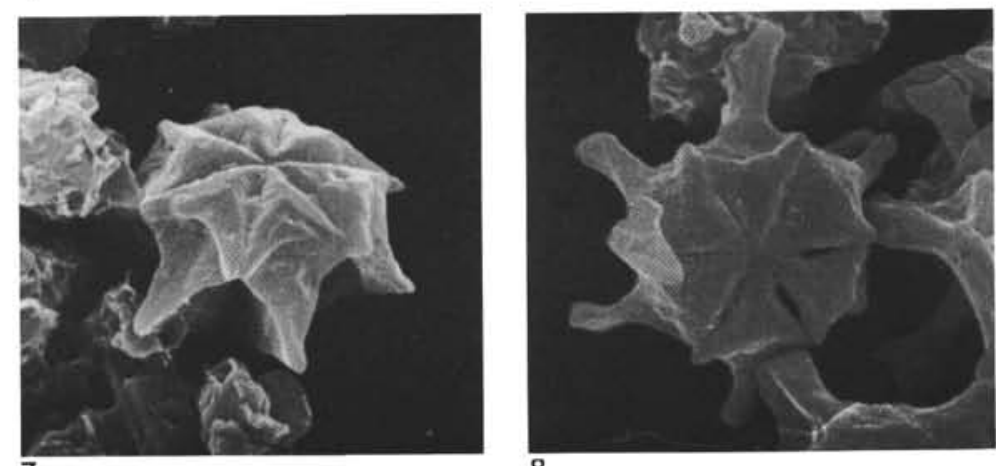

8
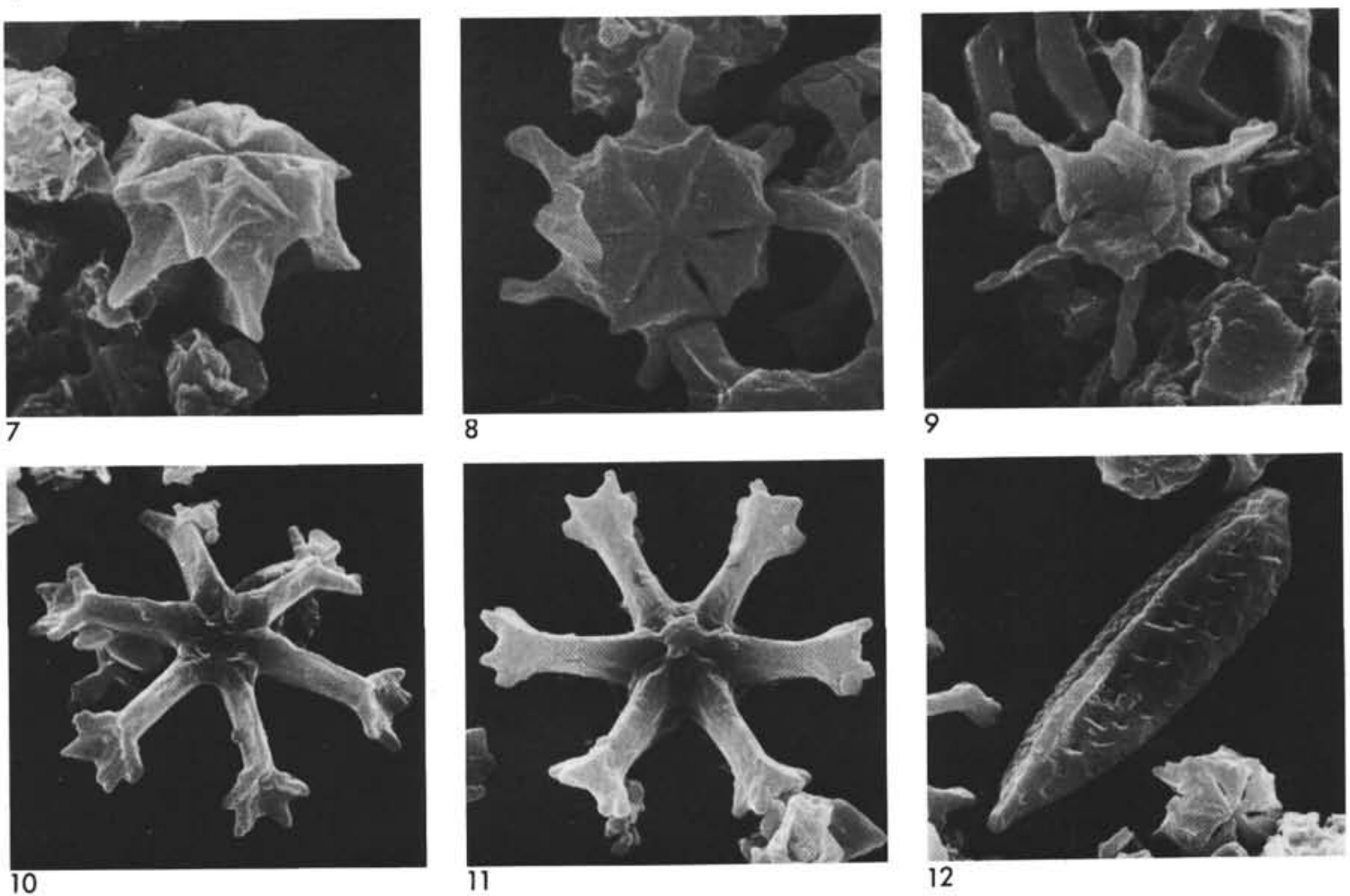

11

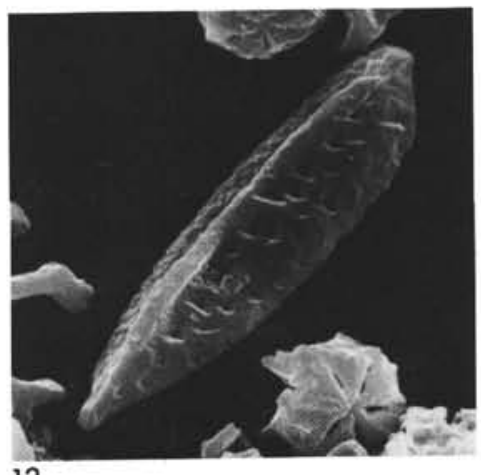

12

Plate 3. Miocene calcareous nannoplankton.

Figures 1-4. Catinaster coalitus Martini and Bramlette, 1963. Figs. 1, 2. $\times 6000$, distal side. Sample 448-1-1, 60-61 cm. Miocene, Zone NN 9. Fig. 3. $\times 6000$, proximal side. Sample 448-1-1, 60-61 cm. Miocene, Zone NN 9. Fig. 4. ×6000, distal side. Sample 448-1-1, $8-9 \mathrm{~cm}$. Miocene, Zone NN 9.

Figures 5-9. Catinaster calyculus Martini and Bramlette, 1963. Figs. 5, 6. $\times 6000$, distal side. Sample 448-1-1, 60-61 cm. Miocene, Zone NN 9. Fig. 7. $\times 6000$, proximal side. Sample 448-1-1, 8-9 cm. Miocene, Zone NN 9. Fig. 8. $\times 6000$, distal side. Sample 448-1-1, 8-9 cm. Miocene, Zone NN 9. Fig. 9. $\times 6000$, distal side. Sample 448-1-1, 60-61 cm. Miocene, Zone NN 9.

Figures 10, 11. Discoaster pseudovariabilis Martini and Worsley, 1971. Fig. 10. $\times 3000$, convex side. Sample 448-1-1, 60-61 cm, Miocene, Zone NN 9. Fig. 11. $\times 3000$, concave side. Sample 448-1-1, 60-61 cm. Miocene, Zone NN 9.

Figure 12. Triquetrorhabdulus rugosus Bramlette and Wilcoxon, 1967. $\times 3000$. Note etching marks. Sample 448-1-1, 60-61 cm. Miocene, Zone NN 9. 


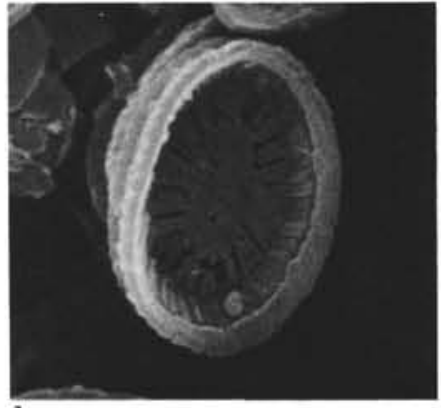

1

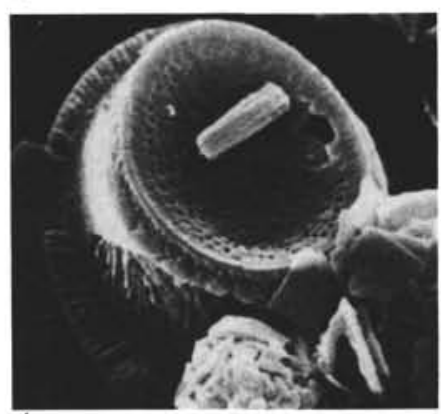

4

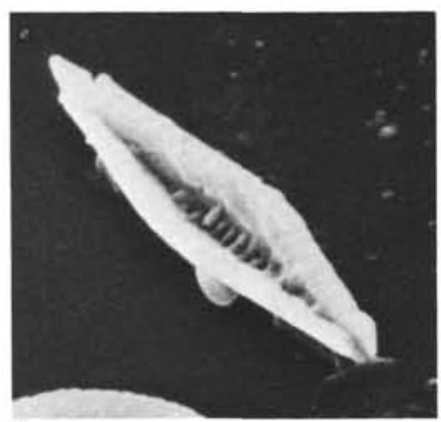

7

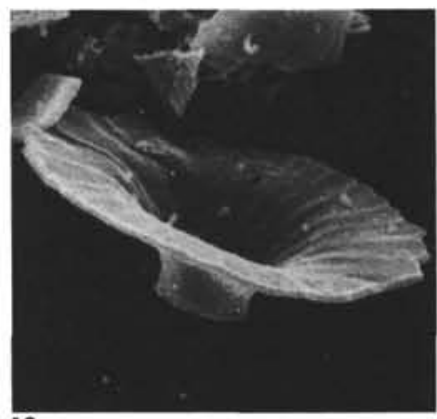

10

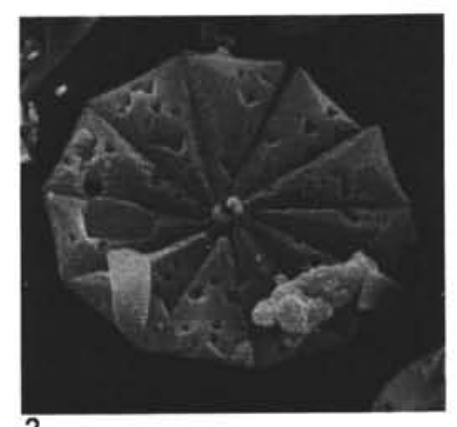

2
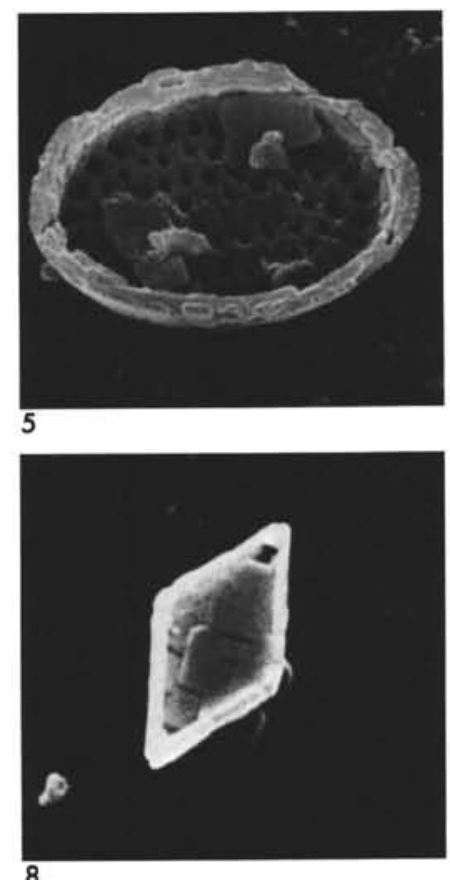

8

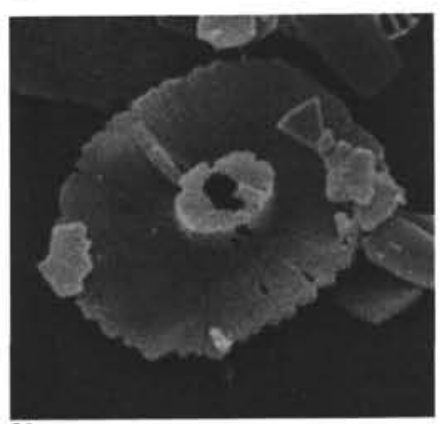

11

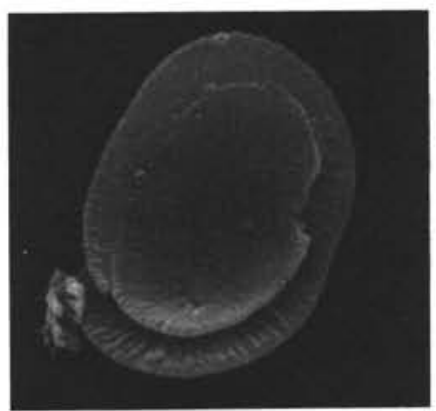

3

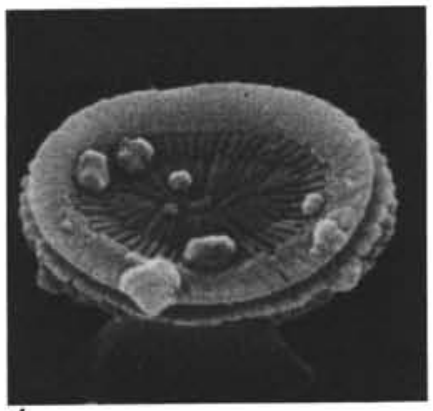

6

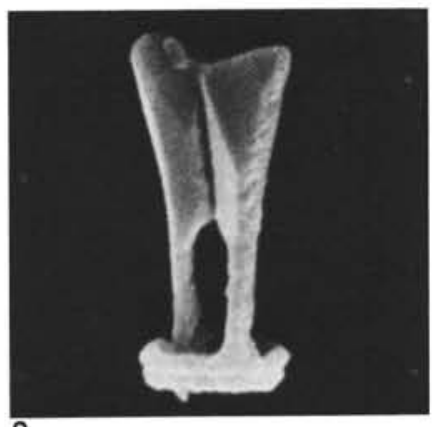

9

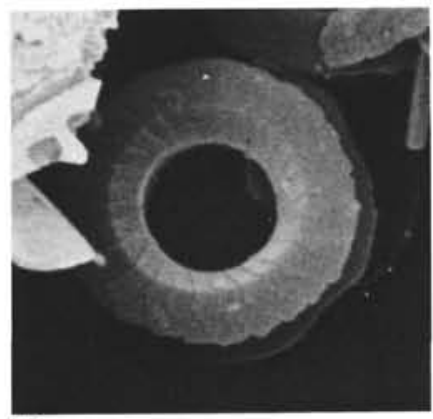

12
Plate 4. Pliocene and Quaternary calcareous nannoplankton.

Figure 1. Coronosphaera cf. mediterranea (Lohmann) Gaarder, 1977. $\times 7000$, distal side. Sample 451-2-3, 29-30 cm. Quaternary, Zone NN 19.

Figure 2. Hayaster perplexus (Bramlette and Riedel) Bukry, 1973. $\times 5000$. Sample 451-2-1, 43-44 cm. Quaternary, Zone NN 19.

Figure 3. Helicosphaera hyalina Gaarder, 1970. $\times 7600$, proximal side. Sample 451-1-2, 1-2 cm. Quaternary, Zone NN 21.

Figure 4. Pontosphaera alboranensis Bartolini, 1970. $\times 5000$, proximal side. Sample 451-2-4, 8-9 cm. Upper Pliocene, Zone NN 18.

Figure 5. Pontosphaera discopora Schiller, 1925. $\times 7000$, distal side. Sample 451-2-2, 68-69 cm. Quaternary, Zone NN 19.

Figure 6. Syracosphaera pulchra Lohmann, 1902. $\times 7000$, proximal side. Sample 451-2-1, 43-44 cm. Quaternary, Zone NN 19.
Figure 7. Scapholithus fossilis Deflandre, 1954. $\times 9500$, distal side. Sample 451-1-2, 1-2 cm. Quaternary, Zone NN 21.

Figure 8. Calciosolenia compacta new species, $\times 10,000$, distal side. Holotype SM.B 13025. Sample 451-2-4, 8-9 cm. Upper Pliocene, Zone NN 18.

Figure 9. Bramletteius? duoalatus new species. $\times 10,000$, side view. Holotype SM.B 13026. Sample 451-2-6, 8-9 cm. Upper Pliocene, Zone NN 17.

Figure 10. Umbellosphaera irregularis Paasche, 1955. $\times 6650$, oblique view of distal side. Sample 451-2, 1-2 cm. Quaternary, Zone NN 21.

Figure 11. Umbellosphaera irregularis Paasche, 1955. $\times 8000$, proximal side. Sample 451-2,CC. Quaternary, Zone NN 21.

Figure 12. Umbilicosphaera sibogae (Weber van Boss) Gaarder, 1970. $\times 9500$, distal side. Sample 451-1-2, 1-2 cm. Quaternary, Zone NN 21. 


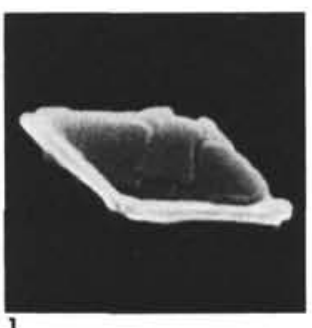

1

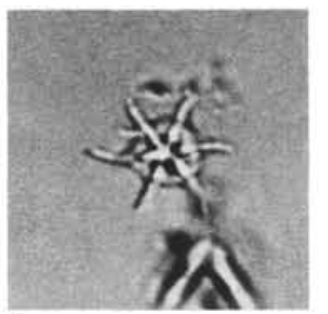

5
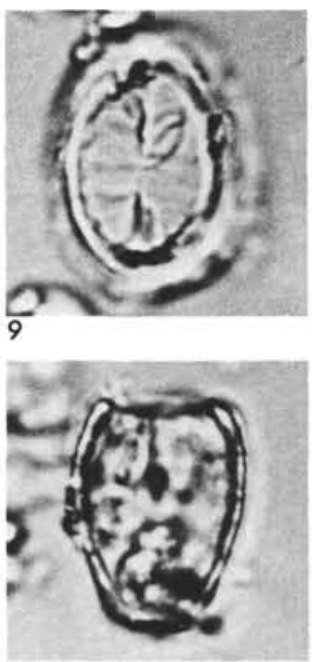

13

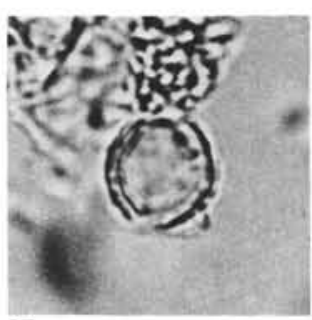

17
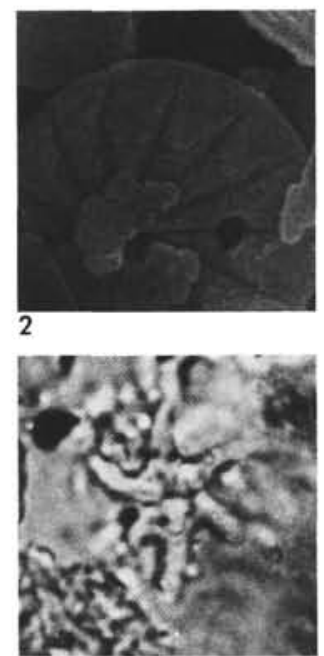

6

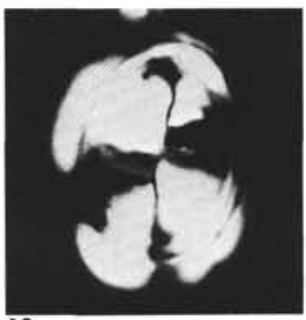

10

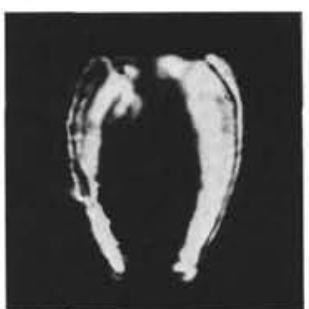

14

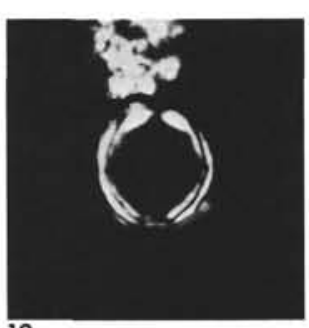

18

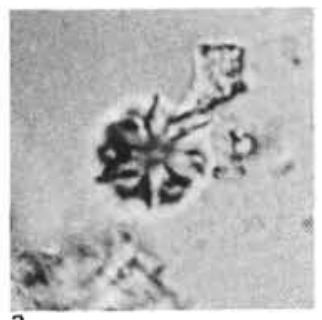

3

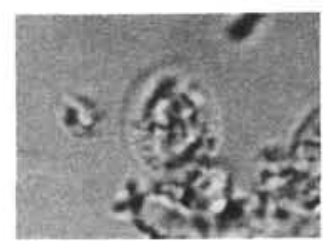

7

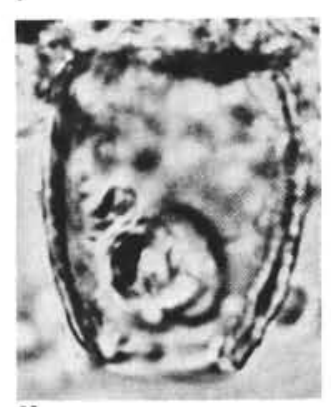

11

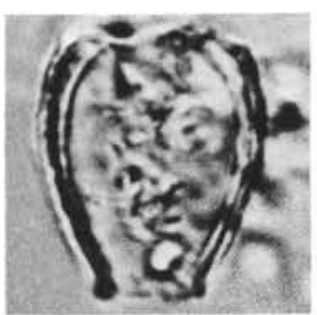

15

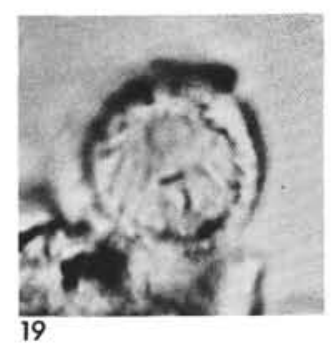

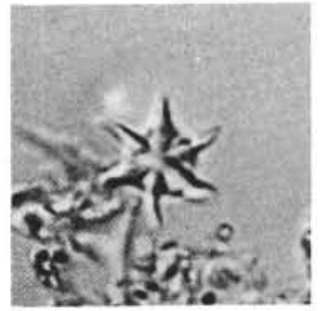

4

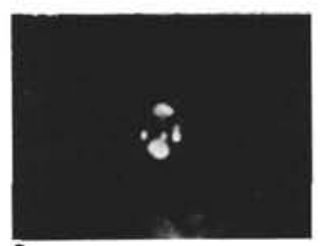

8

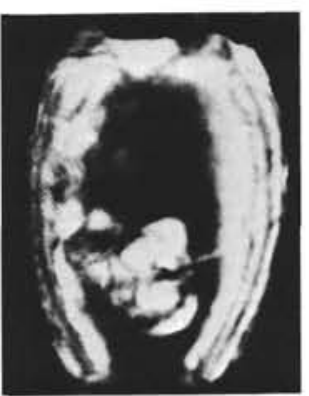

12

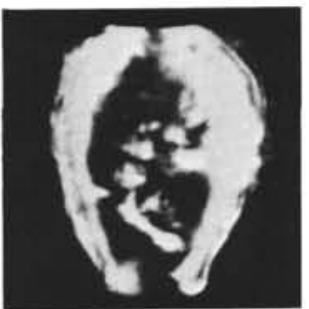

16

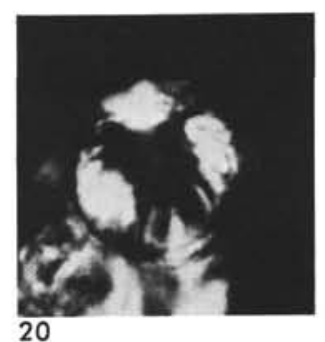

Plate 5. Oligocene to Quaternary calcareous nannoplankton. (All specimens with the exception of Figures 1 and 2 are magnified approximately $\times 2000$.)

Figure 1. Calcisolenia compacta new species. $\times 10,000$, distal side. Sample 451-2-4, 8-9 cm. Upper Pliocene, Zone NN 18.

Figure 2. Hayaster perplexus (Bramlette and Riedel) Bukry, 1973. $\times 10,000$, proximal side. Note perforation. Sample 451-2-1, 43-44 $\mathrm{cm}$. Quaternary, Zone NN 19.

Figures 3-6. Catinaster calyculus Martini and Bramlette, 1963. Fig. 3. Short-rayed form. Sample 450-7,CC. Miocene, Zone NN 8. Fig. 4. Medium-long-rayed form. Sample 450-6-1, 14-15 cm. Miocene, Zone NN 9. Fig. 5. Long-rayed form. Sample 450-4,CC. Miocene, Zone NN 9. Fig. 6. Overcalcified long-rayed form. Sample 451-85-4, 91-92 cm. Miocene, Zone NN 10.

Figures 7, 8. "Coccolithus" sp. Sample 448-5,CC. Lower Miocene, Zone NN 2. (Fig. 8. Long axis $0^{\circ}$ to crossed nicols.)

Figures 9, 10. Scyphosphaera sp. Short-walled lopodolith probably belonging to $S$. recurvata Deflandre, 1942. Proximal side. Sample 448-20-2, 27-28 cm. Oligocene, Zone NP 24. (Fig. 10. Long axis $0^{\circ}$ to crossed nicols.)

Figures 11, 12. Scyphosphaera apsteini Lohmann, 1902. Sample 448-20-2, 27-28 cm. Oligocene, Zone NP 24. (Fig. 12. Long axis $45^{\circ}$ to crossed nicols; side view.)

Figures 13-16. Scyphosphaera recurvata Deflandre, 1942. Figs. 13, 14. Sample 448-20-2, 27-28 cm. Oligocene, Zone NP 24. (Fig. 14. Long axis $45^{\circ}$ to crossed nicols; side view.) Figs. 15, 16. Sample 448-20-2, 29-30 cm. Oligocene, Zone NP 24. (Fig. 16. Long axis $45^{\circ}$ to crossed nicols; side view.)

Figures 17-20. Scyphosphaera globulata Bukry and Percival, 1971. Sample 451-4-1, 9-10 cm. Lower Pliocene, Zone NN 15. (Fig. 18. Long axis $45^{\circ}$ to crossed nicols; side view. Fig. 20. Crossed nicols; oblique view.) 